\title{
Development of Excitable Membrane Properties in Mammalian Sympathetic Neurons
}

\author{
Jeanne M. Nerbonne and Alison M. Gurney ${ }^{\mathrm{a}}$ \\ Department of Pharmacology, Washington University Medical School, St. Louis, Missouri 63110
}

\begin{abstract}
Using the whole-cell patch-clamp recording technique, resting membrane potentials (RPs), action potential (AP) waveforms, and the properties of voltage-activated inward $\mathrm{Na}^{+}$ $\left(I_{\mathrm{Na}}\right)$ and $\mathrm{Ca}^{2+}\left(\mathrm{I}_{\mathrm{Ca}}\right)$ currents and outward $\mathrm{K}^{+}\left(\mathrm{I}_{\mathrm{A}}, \mathrm{I}_{\mathrm{K}}\right)$ currents were examined in embryonic and neonatal rat superior cervical ganglion (SCG) neurons as a function of time during development in vivo and in vitro. The passive and active membrane properties of neonatal SCG cells examined $\leq \mathbf{2 4}$ $\mathrm{hr}$ after isolation were similar to those described previously for adult SCG neurons and for neonatal SCG cells maintained for several weeks in culture. Since recordings were obtained within hours of cell dissociations, it is assumed that the results reflect the membrane properties of neonatal SCG neurons in vivo at the time of isolation. When neonatal cells were examined as a function of time (up to $\approx 2-3$ weeks) in vitro, neither RPs nor AP waveforms varied measurably. Although absolute (inward and outward) current amplitudes increased in cells maintained in vitro, in parallel with increases in cell size, no changes in the time- or voltagedependent properties of the currents were observed. Similar results were obtained for cells isolated on or after embryonic day 18.5 ( $\geq E 18.5)$. The membrane properties of E14.5-16.5 SCG cells examined $\leq \mathbf{2 4} \mathrm{hr}$ after isolation, in contrast, were significantly different: mean $I_{C a}$ density was higher, and APs were broader than in $\geq E 18.5$ cells, and, in addition, $I_{A}$ was absent in these cells. When E14.5-16.5 cells were examined after $\approx 1$ week in vitro, $I_{C \text { a }}$ densities and $A P$ waveforms were indistinguishable from those in $\geq E 18.5$ SCG neurons, and $I_{A}$ was present. These studies reveal that rat SCG neurons are electrophysiologically mature early in development. Even $I_{A}$,
\end{abstract}

\footnotetext{
Received Nov. 7, 1988; revised Feb. 14, 1989; accepted Feb. 15, 1989.

We wish to thank Dr. H. R. Rayburn (Caltech) for participating in some of the early experiments, Joseph Doyle and Becky Tanamachi (Caltech) for expert technical assistance in the preparation and maintenance of embryonic and neonata SCG cultures, David Martin and Chris Wilcox for providing dissociated SCG neurons on several occasions, and, Dr. P. H. Patterson (Caltech) for providing NGF. In addition, we thank Dr. E. M. Johnson, Jr., and colleagues for providing us with NGF and the monoclonal antibody, 192-IgG, and for many helpful comments, suggestions, and discussions. We would also like to thank Drs. H. A. Lester and J. Pine (Caltech) for space and support during the initial phase of this work and Michael Apkon and Kelleen Giffin for critical reading of the manuscript. This work has been supported by the Los Angeles Affiliate of the American Heart Association (Fellowships to J.M.N. and A.M.G.), the National Office of the American Heart Association (Established Investigatorship and Grant-in-Aid to J.M.N.), the Fulbright-Hayes and Welcome Foundations (Travel Grants to A.M.G.), and the National Institutes of Health (GM-29836 to H. A. Lester (Caltech) and HL34161 to J.M.N.).

Correspondence should be addressed to Jeanne M. Nerbonne, Department of Pharmacology, Box 8103, Washington University Medical School, 660 South Euclid Avenue, St. Louis, MO 63110.

a Permanent address: Department of Pharmacology, St. Thomas' Hospital Medical School, London SE1 7EH, United Kingdom.

Copyright (C) 1989 Society for Neuroscience $0270-6474 / 89 / 093272-15 \$ 02.00 / 0$
}

which seems to be the last voltage-gated current to develop, appears well before birth. As the appearance of $I_{A}$ correlates with decreased membrane excitability and AP shortening, it seems likely that the development of $I_{A}$ either reflects or regulates a marked change in the overall input and output properties of developing sympathetic neurons.

Although there is little information available about the development of membrane excitability in the mammalian nervous system, developmental changes in excitable membrane properties have been described in other systems (for review, see Spitzer, 1983, 1984). In spinal cord neurons from Xenopus lae$v i s$, for example, action potential (AP) durations shorten markedly during development both in vitro and in vivo (Spitzer and Lamborghini, 1976; Baccaglini and Spitzer, 1977). AP shortening in these cells has been attributed to changes in the ionic basis of the AP. At early times, APs depend primarily on $\mathrm{Ca}^{2+}$ influx, whereas later, $\mathrm{Na}^{+}$entry predominates (Spitzer and Lamborghini, 1976; Baccaglini and Spitzer, 1977; Blair, 1983). The functional increase in $\mathrm{Na}^{+}$conductance reportedly requires protein (Blair, 1983) and RNA (O'Dowd, 1983) syntheses, and it appears to be the relative number of $\mathrm{Na}^{+}$and $\mathrm{Ca}^{2+}$ channels, as well as the total number of $\mathrm{Na}^{+}$channels, that vary (Blair, 1983; Spitzer, 1984; O'Dowd et al., 1988). Although it is often assumed that this developmental pattern is universal, there have been few systematic studies in other systems to document this assumption and, in fact, exceptions to this general rule have been reported. In avian neural crest cells, for example, developmental increases in $\mathrm{Ca}^{2+}$ current amplitudes and in the $\mathrm{Ca}^{2+}$ dependent component of the AP have been described (Bader et al., 1983a, b). In addition, although APs shorten during the development of Ambystoma spinal neurons, this change is accompanied by an increase (not a decrease) in $\mathrm{Ca}^{2+}$ current density (Barish, 1986).

Developmental variations in AP waveforms could also result from changes in outward $\mathrm{K}^{+}$currents and/or in resting membrane properties instead of, or in addition to, changes in inward currents. Increases in $\mathrm{K}^{+}$current density in Ambystoma spinal neurons (Barish, 1986), for example, appear to account for the AP shortening observed during the development of these cells. Recently, developmental increases in the densities of $\mathrm{Ca}^{2+}$-dependent and $\mathrm{Ca}^{2+}$-independent $\mathrm{K}^{+}$currents ( $\mathrm{O}^{\prime}$ Dowd et al., 1988), as well as increased $\mathrm{Ca}^{2+}$ sensitivity of $\mathrm{K}^{+}$channels (Blair and Dionne, 1985), also have been described in Xenopus sensory neurons. It seems likely that these effects could also account for or contribute to the observed developmental changes in AP waveforms in these cells (Spitzer and Lamborghini, 1976; Baccaglini and Spitzer, 1977). In other preparations, such as Drosophila flight muscle, developmental changes in $\mathrm{K}^{+}$currents that correlate with reshaping the AP also have been described (Sal- 
koff, 1981; Salkoff and Wyman, 1983). Taken together, these studies suggest not only that inward and outward currents can change during development but also that the precise developmental sequence may not be stereotyped in all cells.

The principal obstacle to electrophysiological studies of the developing mammalian nervous system has been the small sizes of the neurons and the resultant difficulties associated with impaling cells with intracellular microelectrodes. With the advent of "tight-seal" (patch-clamp) recording techniques (Hamill et al., 1981; Sakmann and Neher, 1984), it now is possible to study AP waveforms and membrane currents reliably in small cells. This methodology also allows more effective separation and, as a result, more complete characterization of ionic currents than was previously possible. Here, we report the results of studies that employed the whole-cell recording technique to measure resting membrane potentials (RPs), APs, and membrane currents in superior cervical ganglion (SCG) neurons during development in vivo and in vitro. The SCG was selected for two reasons: (1) previous studies have characterized the physiological properties of mature (i.e., adult) cells (Galvan and Sedlmeir, 1984; Belluzzi et al., 1985a, b; Marrion et al., 1987) and of neonatal SCG neurons maintained in long-term culture ( $\mathrm{O}^{\prime}$ Lague et al., 1978a, b; Wakshull et al., 1979; Higgins and Burton, 1982; Freschi, 1983), and (2) the morphological development of the ganglion in vivo has been studied in detail (Rubin, 1985ac). The results reveal that electrically excitable membrane properties in mammalian sympathetic neurons are highly developed by late embryonic life.

A preliminary report of a portion of this work has been published previously as a rapid communication (Nerbonne et al., 1986).

\section{Materials and Methods}

Preparation of cultures. Dissociated embryonic and neonatal rat SCG neurons were prepared using procedures similar to those previously described (Mains and Patterson, 1973; Wakshull et al., 1979; Hawrot, 1980; Johnson and Argiro, 1983). Briefly, ganglia were dissected and incubated in $\mathrm{Ca}^{21}, \mathrm{Mg}^{2+}$-free Hanks' balanced salt solution containing $0.5 \%$ trypsin (Gibco) at $37^{\circ} \mathrm{C}$ for $30 \mathrm{~min}$. After transferring into Eagle's minimum essential medium supplemented with $10 \%$ defined horse serum (Hyclone, inactivated by heating at $56^{\circ} \mathrm{C}$ for $30 \mathrm{~min}$ ), penicillin/ streptomycin (Gibco, 100 units $/ \mathrm{ml}$ ), $20 \mathrm{~mm}$ glutamine, and $1 \mu \mathrm{g} / \mathrm{ml} 7 \mathrm{~S}$ nerve growth factor, cells were dispersed by gentle trituration (Johnson and Argiro, 1983) and plated at $\sim 3000$ cells $/ \mathrm{cm}^{2}$ on rat tail collagen. Within $\sim 6 \mathrm{hr}$ of plating, cells adhered to the substrate and began to extend processes. Cultures could be maintained for up to 6 weeks with medium changes every 2-3 d. In cultures maintained for longer than 5 $\mathrm{d}$, the growth of non-neuronal cells was inhibited by the addition of 10 $\mu \mathrm{M}$ cytosine arabinoside (ARAC) to the medium for $48 \mathrm{hr}$ on day 4 . Alternatively, dissociated cells could be plated in the presence of ARAC, although with embryonic cultures, this procedure resulted in the death of a substantial number of neurons. In some experiments, dissociated SCG neurons were plated on monolayers of cultured rat cortical astrocytes (Raff et al., 1979). Within 2-3 hr, cells adhered to this substrate, and process outgrowth was evident. Although we are not certain why adhesion and process outgrowth are accelerated when cells are plated on astrocytes, similar results have been obtained with other neuronal cell types (J. M. Nerbonne and J. Doyle, unpublished observations). In the experiments here, the use of astrocyte monolayers (as substrates) facilitated measurements of APs, RPs, and voltage-activated ionic currents in developing SCG neurons within the first 2-3 hr after dissociation.

Timed-pregnant Wistar and Sprague Dawley rats were obtained from Hilltop Lab Animals, Inc. (Scottdale, PA) and Chappel Breeders, Inc. (St. Louis, MO), respectively. Embryonic age was determined by counting the first day after mating and the appearance of a sperm-positive plug as embryonic day 0 (E0). Since some variation in the total gestation period was observed, embryos were staged also by external appearance (Christie, 1964). Embryonic ages (E14.5-20) assigned here reflect the latter method of staging; we assume these assignments to be accurate to within $\sim 0.5$ day. Timed-pregnant rats were killed, and embryos were delivered by cesarean section. Neonates were used within $24-48 \mathrm{hr}$ of delivery.

Immunohistochemistry. The monoclonal antibody 192-lgG (Chandler et al., 1984), purified from mouse ascites fluid, was provided by E.M. Johnson, Jr. (Washington University, St. Louis, MO), and immunohistochemistry on dissociated SCG cultures was performed as described by Taniuchi et al. (1986). Affinity purified biotinylated horse antimouse IgG (heavy- and light-chain specific, preabsorbed to remove cross-reactivity to rat $\operatorname{IgG}$ ), avidin $\mathrm{DH}$, and biotinylated alkaline phosphatase $\mathrm{H}$ were obtained from Vector Laboratories (Burlingame, $\mathrm{CA}$ ) as part of an $\mathrm{ABC}$ kit (AK-5200), as were the reagents for visualizing the avidinbiotin alkaline phosphatase complex (SK-5200).

Before staining, dissociated SCG cultures were fixed in $4 \%$ paraformaldehyde in 0.10 м phosphate buffer $(\mathrm{PB})$ at $\mathrm{pH} 7.2$ overnight at $4^{\circ} \mathrm{C}$. Following washing with $\mathrm{PB}$, cultures were incubated for $1 \mathrm{hr}$ in $\mathrm{PB}$ containing $5 \%$ heat-inactivated horse serum (HS) before exposure to $192-\operatorname{lgG}(5 \mu \mathrm{g} / \mathrm{ml}$ in $\mathrm{PB}$ with $5 \% \mathrm{HS})$ for $\mathrm{l}-2 \mathrm{hr}$. The primary antibody was removed, and the cultures were washed several times with $P B$ before a $1 \mathrm{hr}$ incubation with the secondary antibody, biotinylated horse antimouse $\operatorname{IgG}(1 \mu \mathrm{g} / \mathrm{ml}$ in PB with $5 \% \mathrm{HS})$. After washing several times with $\mathrm{PB}$ over $10 \mathrm{~min}$, cultures were incubated with a complex of avidinbiotinylated alkaline phosphatase for $1 \mathrm{hr}$, followed by a $15-\mathrm{min}$ exposure to alkaline phosphatase substrate II, which produced a brownblack reaction product. All incubations were performed at $22^{\circ} \mathrm{C}$. Cultures were visualized and photographed directly and later mounted for permanent storage.

Electrophysiological recordings. The whole-cell recording method (Hamill et al., 1981) was employed to measure RPs, APs, and ionic currents. The voltage/current-clamp circuit was provided by a Dagan (Model 8900) patch-clamp/whole-cell clamp with a $1 \mathrm{G} \Omega$ feedback resistor. Recording pipettes were fabricated from flint glass, and the shanks, up to the tips, were coated with Sylgard to reduce pipette capacitance. Pipettes, after fire-polishing, had tip diameters of 0.5 to $1.0 \mu \mathrm{m}$ and resistances of 2-4 M $\Omega$ when filled with recording solution (see below). After formation of a high-resistance (giga) seal between the recording electrode and the cell membrane, pipette capacitances were compensated electronically before establishing the whole-cell configuration. Series resistances, estimated from the decay of the whole-cell (uncompensated) capacitative transients, were generally $1.5-2 \times$ pipette resistance (Marty and Neher, 1983). Since series resistances could be compensated by $\geq 90 \%$, voltage errors (resulting from the uncompensated series resistance) are expected to be small: $\leq 5 \mathrm{mV}$ for currents of $\leq 8 \mathrm{nA}$. The results presented here are uncorrected. Series resistance compensation was checked at regular intervals during the course of each experiment, and data were discarded if increases in series resistance were evident. Linear leakage currents were subtracted before data were digitized and stored. All experimental parameters, e.g., holding potentials (HPs), test potentials, and the timing and durations of experimental trials, were controlled with an IBM PC equipped with an analog interface (Model 20009, Tecmar Co.). Current signals were filtered at $3 \mathrm{kHz}$, digitized, and stored on floppy disks. The P-CLAMP software package (Axon Instruments) was used in data acquisition, and data analyses were performed using either P-CLAMP or ASYSTANT (Macmillan Software).

For RP and AP measurements, bath solutions contained (in $\mathrm{mM}$ ): $\mathrm{NaCl}, 140 ; \mathrm{CaCl}_{2}, 5 ; \mathrm{KCl}, 4 ; \mathrm{MgCl}_{2}$, 2; Hepes, 5; glucose, 5; $\mathrm{pH}$ 7.4. Recording pipettes were filled with (in $\mathrm{mM}$ ): $\mathrm{KCl}, 140$; Hepes, 5; glucose, 5; and EGTA, 0.5-10, at $\mathrm{pH} 7.3$. In some experiments, ATP at $3 \mathrm{~mm}$ and GTP at $100 \mu \mathrm{M}$ were also added. Variations of these solutions were employed in voltage-clamp experiments. Although more stable recordings were obtained in low $(0.5-2.0 \mathrm{~mm})$ EGTA pipette solutions supplemented with ATP and GTP, neither the addition of nucleotides nor the EGTA concentration influenced the waveforms of the currents or APs. Inward currents were separated from overlapping outward $\mathrm{K}^{+}$ currents by replacing the $\mathrm{KCl}$ in the recording pipettes with isotonic $\mathrm{CsCl}$. In most cases, the $\mathrm{Cs}^{+}$, apparently via intracellular dialysis, effectively blocked $>95 \%$ of the total outward current. The fast, inward $\mathrm{Na}^{+}$current $\left(\mathrm{I}_{\mathrm{Na}}\right)$ was suppressed by the addition of $1-2 \mu \mathrm{M}$ TTX to the bath or by inactivation at depolarized HPs $(-30$ to $-50 \mathrm{mV})$. Under these conditions, the slow inward calcium current $\left(\mathrm{I}_{\mathrm{C} a}\right)$ was studied. $\mathrm{I}_{\mathrm{Na}}$ was isolated by blocking $I_{\mathrm{Ca}}(>95 \%)$ with $\mathrm{CoCl}_{2}(5 \mathrm{mM})$ included in a low (1 mM) Ca ${ }^{2+}$ bath solution; extracellular $\mathrm{Ca}^{2+}$ could not be removed 
completely since this resulted in unstable recordings, presumably because the cells became leaky. Outward currents, recorded with $140 \mathrm{~mm}$ $\mathrm{KCl}$ in the pipettes, were usually measured after blockade of $I_{\mathrm{Na}_{a}}$ and $\mathrm{I}_{\mathrm{Ca}}$. The fast, transient " $A$ " current $\left(\mathrm{I}_{A}\right)$ and the slower activating, i.e., "delayed," current $\left(I_{K}\right)$ were routinely separated by varying HPs and test potentials. In some experiments, separation of $I_{A}$ and $I_{K}$ was facilitated by the addition of tetraethylammonium (TEA) chloride (isosmotic replacement for $\mathrm{NaCl}$ ) or 4-aminopyridine (4-AP) to the bath. In experiments conducted in normal $\mathrm{Ca}^{2+}$ bath solution, the sums of $\mathrm{Ca}^{2+}$ dependent and $\mathrm{Ca}^{2+}$-independent outward $\mathrm{K}^{+}$currents were measured. In general, stable recordings of APs, RPs, and voltage-gated (inward and outward) currents were obtained from embryonic and neonatal SCG cells for $20-60 \mathrm{~min}$. All recordings were obtained at $20-22^{\circ} \mathrm{C}$.

The effects of 1-3 mM 4-AP on the waveforms of outward $\mathrm{K}^{+}$currents and APs were evaluated during electrophysiological recordings by pressure applications from small $(2-4 \mu \mathrm{m})$ puffer pipettes placed within $\approx 25$ $\mu \mathrm{m}$ of the cell surface. In all experiments, two puffer pipettes were employed: (1) the experimental pipette contained the test drug in bath solution, and (2) the control pipette contained bath solution. Drug solutions were prepared immediately before use by diluting frozen stocks in the appropriate bath solution.

Cell membrane capacitances were measured by integrating the capacitative current transients evoked during small (5-20 mV) hyperpolarizing or depolarizing voltage clamp steps. These measurements were used to calculate membrane surface areas (Sakmann and Neher, 1984) from which cell diameters were estimated, assuming the cells to be spherical. Cell sizes, current densities, etc., are presented as mean \pm SD. The statistical significance of apparent differences among cells isolated at various development times or among cells maintained for varying times in vitro was evaluated by applying the Student's $t$ test, and $p$ values are presented. Rate constants for outward current activation were determined from single exponential fits to the rising phases of the currents after the first few milliseconds. The current waveforms were analyzed in this way to provide reliable estimates of the time course of outward current activation for qualitative comparisons of different cell populations. These analyses do not reflect any underlying mechanistic interpretation about current properties. Rate constants are presented as mean \pm SEM.

\section{Results}

\section{Cell cultures}

As previously demonstrated (Wakshull et al., 1979; Johnson and Argiro, 1983), SCG neurons enzymatically dissociated from neonatal and late embryonic (E18-20) rat pups survive, extend processes, and make synaptic contacts in vitro. Similar procedures allowed dissociation of E14.5-18 ganglia. Mechanical methods for dispersing cells (Johnson and Argiro, 1983) were unreliable in our hands. Although attempts were made to isolate ganglia at earlier stages, it was not possible to distinguish the SCG from other nearby ganglia before $\approx E 14.5$. This probably is not surprising, since the SCG, first detectable at E12-14, does not coalesce into a well-separated ganglion until E14-16 (Rubin, 1985a). In fact, in dissociated cultures prepared at E14.5-16.5, several morphologically distinct cell types were evident, only one of which resembled SCG neurons isolated at $\geq E 18$. As it seemed likely that the unidentified cells arose from nearby ganglia removed with the SCG, binding to the monoclonal antibody 192-IgG, directed against the NGF receptor (Chandler et al., 1984), was examined. In dissociated cultures prepared from E14.5-16.5 ganglia, $\approx 30 \%$ of the cells did not stain with $192-$ $\mathrm{IgG}$, whereas essentially all ( $\geq 95 \%$ ) neurons in $\geq \mathrm{E} 18$ SCG cultures were 192-IgG positive. Although false positives might be expected owing to the apparent presence of NGF receptors on neurons not derived from the neural crest, there is no evidence for false negatives, since all sympathetic neurons appear to stain with 192-IgG (Richardson et al., 1986). As a result, it seems unlikely that neurons that did not stain with 192-IgG were derived from the SCG (Richardson et al., 1986). In cultures prepared on or before E16.5, neurons that were similar in appearance to mature SCG neurons were also $192-\mathrm{IgG}$ positive. This observation supports the contention that SCG neurons can be readily identified, even in mixed cultures. In physiological studies on $\leq \mathrm{E} 16.5$ cultures, cell appearance was used to judge which cells were SCG neurons, and only those cells were compared in the present study.

\section{Voltage-dependent currents}

Previous electrophysiological studies on dissociated SCG neurons were performed on cells derived from neonatal and late embryonic ganglia after $\geq 2-3$ weeks in culture (O'Lague et al., 1978a, b; Wakshull et al., 1979; Higgins and Burton, 1982; Freschi, 1983). Recordings from early embryonic and freshly dissociatcd cells werc accomplished here by employing the "tightseal," whole-cell recording technique (Hamill et al., 1981), and within 2-3 hr of plating, RPs, APs, and voltage-activated currents could be measured. This time corresponded to the time required for cells to adhere to the substrate, and recordings were not attempted earlier. Although SCG neurons isolated at E20neonatal were significantly $(p<0.001)$ larger than those dissociated at E14.5-16.5 (Table 1), there were no differences in the ease with which high resistance membrane-pipette seals and whole-cell recordings were obtained.

When neonatal SCG cells were examined within a few hours of dissociation, depolarizations to potentials positive to -30 $\mathrm{mV}$ from HPs between -40 and $-90 \mathrm{mV}$ revealed inward and outward currents. Although attempts were made to compare the waveforms of the total depolarization-activated currents in E14.5-neonatal SCG cells, differences among cells were difficult to quantify, since inward and outward current components overlapped. As a result, in all subsequent experiments, the properties of the individual current components were examined in isolation. Voltage-dependent inward currents were measured with $\mathrm{Cs}^{+}$in the pipettes. Depolarizations from an $\mathrm{HP}$ of $-80 \mathrm{mV}$ revealed a transient $\mathrm{Na}^{+}$current $\left(\mathrm{I}_{\mathrm{Na}}\right)$ and a more slowly activating, noninactivating, $\mathrm{Ca}^{2+}$ current $\left(\mathrm{I}_{\mathrm{Ca}}\right)$. Similar results have been reported previously for dissociated neonatal SCG cells after $\approx 3$ weeks in vitro (Freschi, 1983) and for adult SCG neurons (Galvan and Sedlmeir, 1984; Belluzzi et al., 1985a, b). It seems certain that $\mathrm{I}_{\mathrm{Na}}$ underlies the rapidly rising phase of the AP in these cells (O'Lague et al., 1978a, b; Higgins and Burton, 1982; Freschi, 1983). In neonatal SCG cells, $I_{\mathrm{Na}}$ was blocked by the addition of TTX to the bath. Although there was some variability in the concentration (1-3 $\mu \mathrm{M})$ required to suppress $\mathrm{I}_{\mathrm{Na}}$ amplitudes by $\geq 95 \%$, there did not appear to be any TTXinsensitive components of $I_{\mathrm{Na}}$. After suppression of $\mathrm{I}_{\mathrm{Na}}$, depolarizations from HPs of -50 to $-60 \mathrm{mV}$ revealed $\mathrm{I}_{\mathrm{Ca}}$, which resembled $\mathrm{Ca}^{2+}$ currents described previously in a variety of neurons (Hagiwara and Byerly, 1981; Kostyuk, 1981), including rat SCG cells (Freschi, 1983; Belluzzi et al., 1985b; Wanke et al., 1987; Hirning et al., 1988). Although it is not clear if $\mathrm{I}_{\mathrm{Ca}}$ contributes to the rising phase of the AP, voltage-dependent $\mathrm{Ca}^{2+}$ influx influences AP waveforms in SCG cells via the activation of $\mathrm{Ca}^{2+}$-dependent outward $\mathrm{K}^{+}$currents, which underlie the afterhyperpolarization phase of the AP (Freschi, 1983; Kawai and Watanabe, 1986; Marrion et al., 1987). Depolarizationactivated outward $\mathrm{K}^{+}$currents $\left(\mathrm{I}_{\mathrm{out}}\right)$ were measured after $\mathrm{I}_{\mathrm{Na}}$ and $\mathrm{I}_{\mathrm{Ca}}$ were blocked by the addition of TTX and $\mathrm{Co}^{2+}$ to the bath; the waveforms of $\mathrm{I}_{\text {out }}$ were similar to those described previously in adult (Galvan and Sedlmeir, 1984; Belluzzi et al., 1985a, b; Marrion et al., 1987) and long-term cultured neonatal (Freschi, 
A.
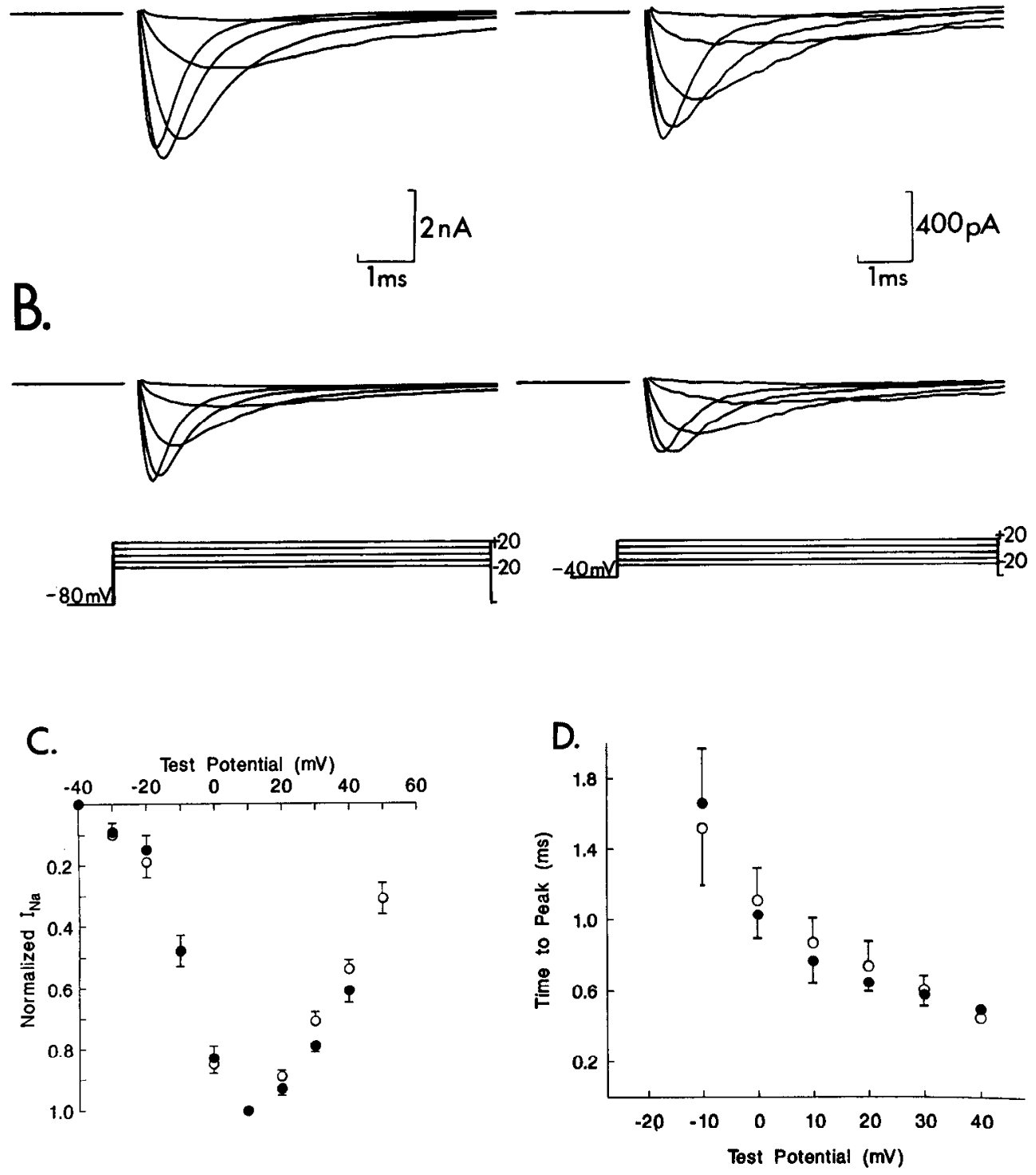

Figure 1. Voltage-gated $\mathrm{Na}^{+}$currents in developing SCG neurons. With $5 \mathrm{mM}$ $\mathrm{Co}^{2+}$ in the bath to block $\mathrm{I}_{\mathrm{Ca}}$ and 140 $\mathrm{mm} \mathrm{Cs}{ }^{+}$in the recording pipettes to block outward $\mathrm{K}^{+}$currents, whole-cell $\mathrm{Na}^{+}$currents $\left(\mathrm{I}_{\mathrm{Na}}\right)$ were measured in developing SCG neurons within the first $24 \mathrm{hr}$ of isolation during depolarizations to potentials between -50 and $+50 \mathrm{mV}$ from HPs of -80 (left panels) and -40 (right panels) $\mathrm{mV}$. From a HP of $-80 \mathrm{mV}, \mathrm{I}_{\mathrm{Na}}$ begins to activate positive to $\approx-40 \mathrm{mV}$ and peaks at $\approx+10$ $\mathrm{mV} . \mathrm{I}_{\mathrm{Na}}$ waveforms in $\mathrm{E} 20(A)$ and $\mathrm{E} 16$ (B) SCG cells are indistinguishable. During depolarizations from an HP of $-40 \mathrm{mV}$ (right panels), $I_{\mathrm{Na}}$ waveforms are similar, although current amplitudes are reduced significantly $(\approx 5$ fold). Peak $\mathrm{I}_{\mathrm{Na}}$ amplitudes in E14.5-16.5 and E20 SCG cells ( $\leq 24 \mathrm{hr}$ after isolation) were measured as a function of test potential and normalized to the current evoked at $+10 \mathrm{mV}$ in the same cell. Mean normalized $I_{\mathrm{Na}}$ values $( \pm$ SEM) for E14.5-16.5 (O, $n=11)$ and E20-neonatal $(0, n=17)$ SCG neurons $(\leq 24 \mathrm{hr}$ in vitro) are plotted as a function of test potential in $C$. Time to peak $I_{\mathrm{Na}}$ values (from the onset of the depolarization) were measured as a function of test potential. Mean normalized time to peak $I_{\mathrm{Na}}$ values $( \pm S D)$ in E14.5$16.5(0, n=10)$ and E20 $(0, n=13)$ SCG neurons $\leq 24 \mathrm{hr}$ after isolation are plotted in $D$.
1983) SCG neurons. Since these preliminary studies revealed that the properties of voltage-gated inward and outward currents in neonatal SCG cells ( $\leq 24 \mathrm{hr}$ after isolation) were (qualitatively) similar to those described previously in mature SCG cells, subsequent experiments were aimed at more quantitative comparisons of current properties as a function of time during development in vivo and in vitro.

\section{Voltage-gated sodium currents}

In E20-neonatal SCG cells examined 4-24 hr after isolation, $I_{\mathrm{Na}}$ was evoked during depolarizations to potentials between -50 and $+50 \mathrm{mV}$ from HPs of -40 to $-80 \mathrm{mV}$ (Fig. 1). From an $\mathrm{HP}$ of $-80 \mathrm{mV}$ (Fig. $1 A$ ), $\mathrm{I}_{\mathrm{Na}}$ begins to activate positive to $\approx-40 \mathrm{mV}$ and peaks at $\approx+10 \mathrm{mV}$. The waveforms of $\mathrm{I}_{\mathrm{Na}}$ evoked from an $\mathrm{HP}$ of $-40 \mathrm{mV}$ (Fig. $1 A$ ) are similar, although absolute current amplitudes are reduced due to steady-state inactivation. Since these cells were examined within a few hr of dissociation, it is assumed that currents measured reflect the properties of $\mathrm{I}_{\mathrm{Na}}$ in vivo at the time of isolation. Similar $\mathrm{I}_{\mathrm{Na}}$ waveforms were recorded in E16.5-18.5 (not shown) and E14.516.5 (Fig. 1B) SCG cells 4-24 hr after dissociation. In addition, the normalized current-voltage relations for $\mathrm{I}_{\mathrm{Na}}$ (Fig. $1 C$ ), as well as the kinetics of $\mathrm{I}_{\mathrm{Na}}$ activation (Fig. $1 D$ ) and inactivation (not shown) in E14.5-16.5 and E20-neonatal SCG cells were indistinguishable. Because the rising phases of the currents evoked at potentials positive to $\approx+20 \mathrm{mV}$ are not well resolved, the time to peak determinations (Fig. $1 D$ ), as well as absolute $\mathrm{I}_{\mathrm{Na}}$ amplitudes, may be underestimated at the more positive test potentials. If this were the case, small differences in kinetics or current-voltage relations at positive test potentials might have gone undetected. Nevertheless, the similarities in the kinetic and voltage-dependent properties of $\mathrm{I}_{\mathrm{Na}}$ (at least up to the peak of the IV relation) in cells isolated at E14.5-birth suggest that the properties of $\mathrm{I}_{\mathrm{Na}}$ do not vary significantly during this developmental period in vivo.

In spite of similarities in current properties, there were large 
Table 1. Variations in cell size in developing SCG neurons

\begin{tabular}{llllr}
$\begin{array}{l}\text { Age at } \\
\text { isolation }\end{array}$ & $\begin{array}{l}\text { Time } \\
\text { in vitro }\end{array}$ & $\begin{array}{l}\text { Cell } \\
\text { capacitance } \\
(\mathrm{pF})^{a . b}\end{array}$ & $\begin{array}{l}\text { Cell diameter } \\
(\mu \mathrm{m})^{a . b}\end{array}$ & $n$ \\
\hline E20-neonatal & $\leq 24 \mathrm{hr}$ & $11.3 \pm 7.3$ & $17.8 \pm 6.6^{c . d}$ & 36 \\
& $48-96 \mathrm{hr}$ & $18.7 \pm 8.6$ & $23.7 \pm 5.6^{c . e}$ & 27 \\
& $5-8 \mathrm{~d}$ & $30.2 \pm 11.7$ & $30.5 \pm 5.6^{c . f}$ & 8 \\
& $2-3 \mathrm{wk}$ & $64.6 \pm 30.1$ & $44.0 \pm 11.0$ & 6 \\
E14.5-16.5 & $\leq 24 \mathrm{hr}$ & $6.1 \pm 3.9$ & $13.3 \pm 4.3^{c . d}$ & 64 \\
& $48-96 \mathrm{hr}$ & $9.1 \pm 5.3$ & $16.3 \pm 5.0^{c . c}$ & 15 \\
& $5-8 \mathrm{~d}$ & $18.5 \pm 7.4$ & $24.2 \pm 5.5^{c . f}$ & 19 \\
& $2-3 \mathrm{wk}$ & $50.8 \pm 18.2$ & $39.5 \pm 7.4$ & 9
\end{tabular}

"Cell capacitances were measured and cell diameters were calculated as described in Materials and Methods.

${ }^{b}$ Values are mean $\pm \mathrm{SD}$.

c Comparisons were made between the mean diameters of SCG cells that were isolated at E14.5-16.5 and E20-neonatal and maintained for the same time (i.e., ${ }^{d} \leq 24 \mathrm{hr}, " 48-96 \mathrm{hr}$, or ${ }^{f} 5-8$ days) in vitro. In all cases, cells isolated at E14.516.5 were significantly $\left({ }^{d} p<0.001,{ }^{\circ} p<0.001,{ }^{f} p<0.02\right)$ smaller than those isolated at E20-neonatal.

variations in absolute $\mathrm{I}_{\mathrm{Na}}$ amplitudes among cells isolated at the same developmental time. In E20-neonatal cells examined $\leq 24$ hr after isolation, for example, peak $\mathrm{I}_{\mathrm{Na}}$ amplitudes (at $+10 \mathrm{mV}$ ) evoked from an $\mathrm{HP}$ of $-80 \mathrm{mV}$ varied $\approx 10$-fold over the range of 0.7 to $7.3 \mathrm{nA}$ (mean $=3.4 \mathrm{nA} ;$ median $=2.7 \mathrm{nA} ; n=16$ ). A similar, although narrower, range was observed in E14.516.5 cells $\leq 24 \mathrm{hr}$ after isolation, and peak $\mathrm{I}_{\mathrm{Na}}$ amplitudes were $0.7-3.6 \mathrm{nA}$ (mean $=2.4 \mathrm{nA} ;$ median $=2.2 \mathrm{nA} ; n=10)$. Peak $\mathrm{Na}^{+}$current densities (Table 2) in E14.5-16.5 and E20-neonatal cells also were similar; the slightly larger mean peak $\mathrm{I}_{\mathrm{Na}}$ density $\left(6.3 \mathrm{pA} / \mu \mathrm{m}^{2}\right)$ for the E14.5-16.5 cells is not statistically significant $(p>0.05)$. These results suggest that $\mathrm{Na}^{+}$channel expression is fully developed in SCG neurons as early as E14.5 (and perhaps earlier) and that $\mathrm{Na}^{+}$current density does not vary significantly between E14.5 and E20 in spite of large increases in cell size (Table 1). To test this hypothesis, attempts were made to evaluate $I_{\mathrm{Na}}$ densities in SCG neurons developing in vitro. Although $\mathrm{I}_{\mathrm{Na}}$ amplitudes increased markedly in SCG cells maintained for $48 \mathrm{hr}$ to 2 weeks in vitro, quantitative measurements of $I_{\mathrm{Na}}$ were complicated by the lack of spatial control of the membrane voltage owing to the extensive elaboration of processes in these cells. The data presented in Table 2 for cells examined at 48-96 hr in vitro reflect the small number of cells in which voltage-clamp control was evident. Although few cells could be analyzed, no differences in peak $I_{\mathrm{Na}}$ densities were apparent.

\section{Voltage-gated calcium currents}

Inward $\mathrm{Ca}^{2+}$ currents $\left(\mathrm{I}_{\mathrm{Ca}}\right)$, evoked during depolarizations to potentials between -20 and $+50 \mathrm{mV}$ from an $\mathrm{HP}$ of $-50 \mathrm{mV}$, were examined in E20-neonatal SCG cells $\leq 24 \mathrm{hr}$ after isolation. In these cells, $I_{C a}$ rises to a peak in $5-10 \mathrm{msec}$ and inactivates only slightly $(\leq 20 \%)$ during $125 \mathrm{msec}$ depolarizations (Fig. $2 A$ ). $\mathrm{I}_{\mathrm{Ca}}$ was partially inactivated at HPs positive to -50 $\mathrm{mV}$, with complete inactivation observed at an HP of $\approx-10$ $\mathrm{mV}$. The waveforms of $\mathrm{I}_{\mathrm{Ca}}$ in E14.5-16.5 SCG cells examined $\leq 24 \mathrm{hr}$ after isolation were similar (Fig. $2 \mathrm{~B}$ ). Since $\mathrm{I}_{\mathrm{Ca}}$ was observed in all embryonic and neonatal SCG neurons examined within hours of isolation, it seems certain $I_{C a}$ was present in these cells in vivo at the time of dissociation from the intact
Table 2. Inward current densities in developing SCG neurons

\begin{tabular}{lllrlr}
$\begin{array}{l}\text { Age at } \\
\text { isolation }\end{array}$ & $\begin{array}{l}\text { Peak } \mathrm{I}_{\mathrm{Na}} \\
\text { density } \\
\text { in vitro }\end{array}$ & $\left(\mathrm{pA} / \mu \mathrm{m}^{2}\right)$ & $n$ & $\begin{array}{l}\text { Peak } \mathrm{I}_{\mathrm{Ca}} \\
\text { density } \\
\left(\mathrm{pA} / \mu \mathrm{m}^{2, c}\right)\end{array}$ & $n$ \\
\hline E20-neonatal & $\leq 24 \mathrm{hr}$ & $4.4 \pm 2.4$ & 16 & $0.57 \pm 0.23^{d}$ & 12 \\
& $48-96 \mathrm{hr}$ & 4.8 & 2 & $0.30 \pm 0.09$ & 13 \\
& $1-3 \mathrm{wk}$ & $\mathrm{ND}^{c}$ & & $0.37 \pm 0.13$ & 6 \\
E14.5-16.5 & $<24 \mathrm{hr}$ & $6.3 \pm 2.4$ & 10 & $1.04 \pm 0.66^{d}$ & 22 \\
& $48 \mathrm{hr}$ & 5.6 & 2 & 0.67 & 2 \\
& $1-2 \mathrm{wk}$ & $\mathrm{ND}^{e}$ & & $0.35 \pm 0.11$ & 8
\end{tabular}

a Determined during depolarizations to $+10 \mathrm{mV}$ from an HP of $-80 \mathrm{mV}$.

${ }^{\circ}$ For $n>2$, values are mean $\pm \mathrm{SD}$. Averages are given for $n=2$.

c Determined during depolarizations to $+20 \mathrm{mV}$ from an HP of $-50 \mathrm{mV}$.

${ }^{d}$ Mean peak $\mathrm{I}_{\mathrm{Ca}}$ density was significantly $(p<0.05)$ higher in E14.5-16.5 (than in E20-neonatal) SCG cells examined $\leq 24 \mathrm{hr}$ after isolation.

' ND, not determined.

ganglia. In addition, the normalized current-voltage relations for $\mathrm{I}_{\mathrm{Ca}}$ (Fig. 1C) and the kinetics of $\mathrm{I}_{\mathrm{Ca}}$ activation (not shown) in E14.5-16.5 and E20-neonatal cells ( $\leq 24 \mathrm{hr}$ after isolation) are indistinguishable. The properties of $\mathrm{I}_{\mathrm{Ca}}$ are similar to those of the "high-voltage threshold" (Carbone and Lux, 1984) or "L"-type (Nowycky et al., 1985; McCleskey et al., 1986; Fox et al., $1987 \mathrm{a}, \mathrm{b}) \mathrm{Ca}^{2+}$ currents/channels previously described in a variety of excitable cells, including sympathetic neurons (Wanke et al., 1987; Hirning et al., 1988). During depolarizations from more hyperpolarized HPs $(-70$ to $-90 \mathrm{mV})$, there was also an inactivating $\mathrm{Ca}^{2+}$ current component evident in some cells. Similar observations made previously have been attributed to the presence of "N"-type Ca ${ }^{2+}$ currents/channels (Wanke et al., 1987; Hirning et al., 1988), similar to those described in DRG neurons (Nowycky et al., 1985; McCleskey et al., 1986; Fox et al., 1987a, b). We have not examined the developmental properties of this current type. In agreement with previous reports (Wanke et al., 1987; Hirning et al., 1988), we find no evidence for the presence of "low-voltage threshold" (Carbone and Lux, 1984) or "T"-type (Nowycky et al., 1985; Fox et al., 1987a, b) $\mathrm{Ca}^{2+}$ currents/channels in rat SCG neurons.

Although similar in neonatal and embryonic SCG cells, the waveforms of $\mathrm{I}_{\mathrm{Ca}}$ measured here (Fig. 2, $A, B$ ) are different from those reported previously for cultured (4-6 weeks) neonatal (Freschi, 1983) and adult (Belluzzi et al., 1985b) SCG neurons. In those studies, $I_{\mathrm{Ca}}$ activated and inactivated rapidly, and the current-voltage relation for $I_{C a}$ peaked between -20 and $0 \mathrm{mV}$. In order to determine if these differences could be attributed to developmental changes in $I_{\mathrm{Ca}}$ properties or, alternatively, to the different recording conditions employed, $I_{C a}$ waveforms were evaluated under conditions similar to those used in the microelectrode studies. With $\mathrm{K}^{+}$in the recording pipettes and 30 mM TEA in the bath to block outward $\mathrm{K}^{+}$currents, depolarizations revealed inward currents that peaked at $\approx 0 \mathrm{mV}$ and decayed $\geq 50 \%$ within $125 \mathrm{msec}$. In addition, net outward currents were observed during large depolarizations (data not shown). These observations suggest that $30 \mathrm{~mm}$ extracellular TEA was insufficient to suppress all (voltage- and $\mathrm{Ca}^{2+}$-dependent) outward $\mathrm{K}^{+}$currents in isolated SCG neurons and that the whole-cell recording configuration is preferable for quantitative studies, since it allows direct measurement of $I_{C a}$ (in the absence of contaminating outward $\mathrm{K}^{+}$currents).

As observed for $\mathrm{I}_{\mathrm{Na}}$, there were significant differences in the 


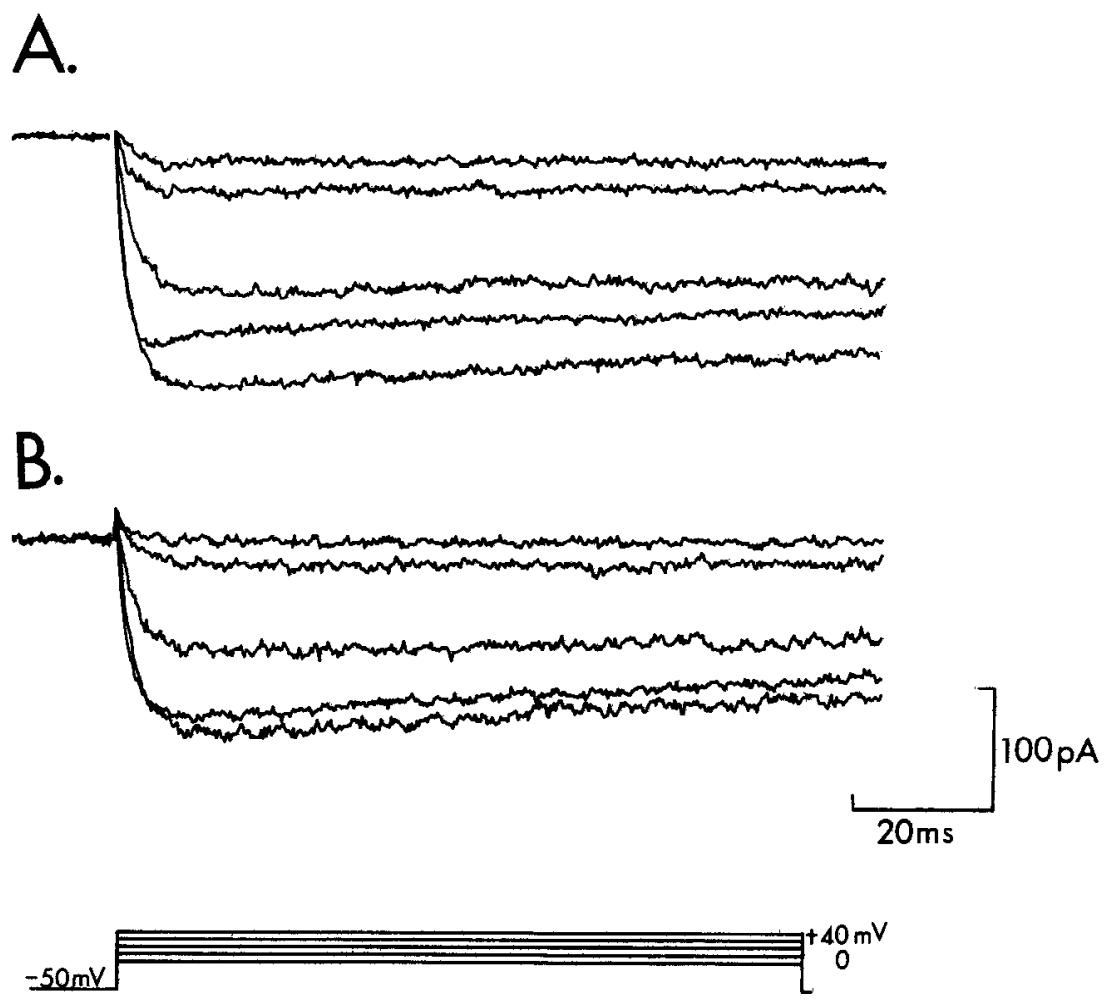

Figure 2. Voltage-gated $\mathrm{Ca}^{2+}$ currents in developing SCG neurons. With the $\mathrm{Co}^{2+}$ in the bath replaced by $5 \mathrm{mM} \mathrm{Ca}^{2+}$ and $2 \mu \mathrm{M}$ TTX added to block $\mathrm{I}_{\mathrm{Na}}$, whole-cell $\mathrm{Ca}^{21}\left(\mathrm{I}_{\mathrm{Ca}_{\mathrm{a}}}\right)$ currents were evoked during depolarizations to -20 to $+50 \mathrm{mV}$ from an $\mathrm{HP}$ of $-50 \mathrm{mV}$. The waveforms of $1_{C a}$ in neonatal $(A)$ and E14.5 $(B)$ SCG cells measured $\leq 24$ $\mathrm{hr}$ after isolation are indistinguishable. $\mathrm{I}_{\mathrm{Ca}}$ amplitudes in E14.5-16.5 and E20neonatal SCG cells $(\leq 24 \mathrm{hr}$ after isolation) were measured as a function of test potential and normalized to the current evoked at $+20 \mathrm{mV}$ in the same cell. Mean normalized $I_{C a}$ values were then determined and are plotted in $C$ for E14.5-16.5 $(O, n=23)$ and E20neonatal $(\varphi, n=12)$ cells; error bars represent \pm SEM. $D$, Similar analyses of $\mathrm{I}_{\mathrm{Ca}}$ waveforms in E14.5-16.5 SCG cells as a function of time in vitro do not reveal any significant differences in the voltage dependence of $\mathrm{I}_{\mathrm{Ca}}$ for cells examined $\leq 24 \mathrm{hr}(\mathrm{O}, n=23)$ and $1-2$ weeks $(\Delta, n=9)$ after isolation; error hars represent \pm SEM.

absolute amplitudes of $\mathrm{I}_{\mathrm{Ca}}$ among SCG neurons isolated at the same developmental time. For E20-neonatal cells examined $\leq 24 \mathrm{hr}$ after isolation, for example, peak $\mathrm{I}_{\mathrm{Ca}}$ amplitudes at +20 $\mathrm{mV}$ evoked from an $\mathrm{HP}$ of $-50 \mathrm{mV}$ varied $\approx 10$-fold, over the range 0.10 to $1.0 \mathrm{nA}$ (mean $=0.50 \mathrm{nA} ;$ median $=0.31 \mathrm{nA} ; n$ $=12$ ). Similar variations were seen in E14.5-16.5 cells, with peak $\mathrm{I}_{\mathrm{Ca}}$ amplitudes ranging from 0.10 to $1.1 \mathrm{nA}$ (mean $=0.35$ $\mathrm{nA}$; median $=0.25 \mathrm{nA} ; n=22$ ). After normalizing for differences in cell sizes (Table 1 ), mcan $\mathrm{I}_{\mathrm{Ca}}$ density was significantly $(p<$ 0.05 ) higher in E14.5-16.5 than in E20-neonatal cells (Table 2). These results suggest not only that the expression of $I_{C a}$ channels is fully developed as early as E14.5 but also that $I_{C a}$ densities decrease during development in vivo between E14.5 and birth, as the cells increase in size. In addition, peak $\mathrm{I}_{\mathrm{Ca}}$ densities continued to decrease significantly $(p<0.01)$ to $\approx 0.35$ $\mathrm{pA} / \mu \mathrm{m}^{2}$ in both E14.5-16.5 and E20-neonatal cells maintained in vitro (Table 2). In contrast, neither the kinetics nor the volt- age-dependent properties (Fig. $2 D$ ) of $\mathrm{I}_{\mathrm{Ca}}$ varied significantly in cells developing in vitro (or in vivo).

\section{Voltage-dependent outward currents}

With $\mathrm{K}^{+}$in the pipettes, depolarizations from HPs between -30 and $-100 \mathrm{mV}$ revealed net outward currents $\left(\mathrm{I}_{\text {out }}\right)$ in neonatal SCG cells examined $\leq 24 \mathrm{hr}$ after isolation. Although the absence of TTX distorted the rising phases of $I_{\text {out }}$, there did not appear to be a component of $\mathrm{I}_{\text {out }}$ that was dependent on $\mathrm{Na}^{+}$ influx (Bader et al., 1985). In contrast, the rates of rise, as well as the peak and the steady-state amplitudes of $I_{\text {out }}$, were sensitive to extracellular $\mathrm{Ca}^{2+}$ (Fig. 3). With $10 \mathrm{mM} \mathrm{Ca}^{2+}$ in the bath, $\mathrm{I}_{\text {out }}$ evoked from an HP of $-50 \mathrm{mV}$ rose to a peak in a few milliseconds and inactivated only slightly during $125 \mathrm{msec}$ depolarizations (Fig. $3 A$ ); in some cells, an inward current (presumably $\mathrm{I}_{\mathrm{Ca}}$ ) was also apparent (Fig. $3 A$ ). When extracellular $\mathrm{Ca}^{2+}$ was reduced to $1 \mathrm{~mm}$ and 5-10 $\mathrm{mM} \mathrm{Co} \mathrm{Co}^{2+}$ was added to the bath, the 
Figure 3. $\mathrm{Ca}^{2+}$-dependent and $\mathrm{Ca}^{2+}$ -

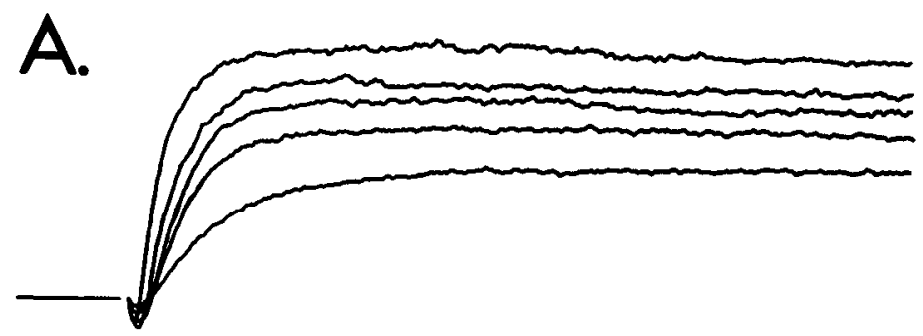
independent components of outward $\mathrm{K}^{+}$ current in a neonatal SCG cell. Currents were evoked during depolarizations to potentials positive to $-20 \mathrm{mV}$ from an $\mathrm{HP}$ of $-50 \mathrm{mV}$. The recording pipette contained $140 \mathrm{~mm} \mathrm{KCl}$. $A$, With $10 \mathrm{~mm}$ $\mathrm{Ca}^{2+}$ in the bath to maximize $\mathrm{I}_{\mathrm{Ca}}$, total voltage- and $\mathrm{Ca}^{2+}$-activated $\mathrm{K}^{+}$currents (as well as $\mathrm{I}_{\mathrm{Ca}}$ ) were measured. $B$, The bath was then replaced with a solution containing low (1 mM) $\mathrm{Ca}^{2+}$ and $5 \mathrm{mM}$ $\mathrm{Co}^{2+}$, and $\left(\mathrm{Ca}^{2+}\right.$-independent) $\mathrm{K}^{+}$currents were measured. In the presence of extracellular $\mathrm{Ca}^{2+}(A), \mathrm{I}_{\text {out }}$ was larger and activated faster than when $I_{C a}$ was blocked $(B)$. The difference $(C)$ between the currents in $B$ and $A$ reflects the sum of $\mathrm{I}_{\mathrm{Ca}}$ and $\mathrm{Ca}^{2+}$-activated currents.
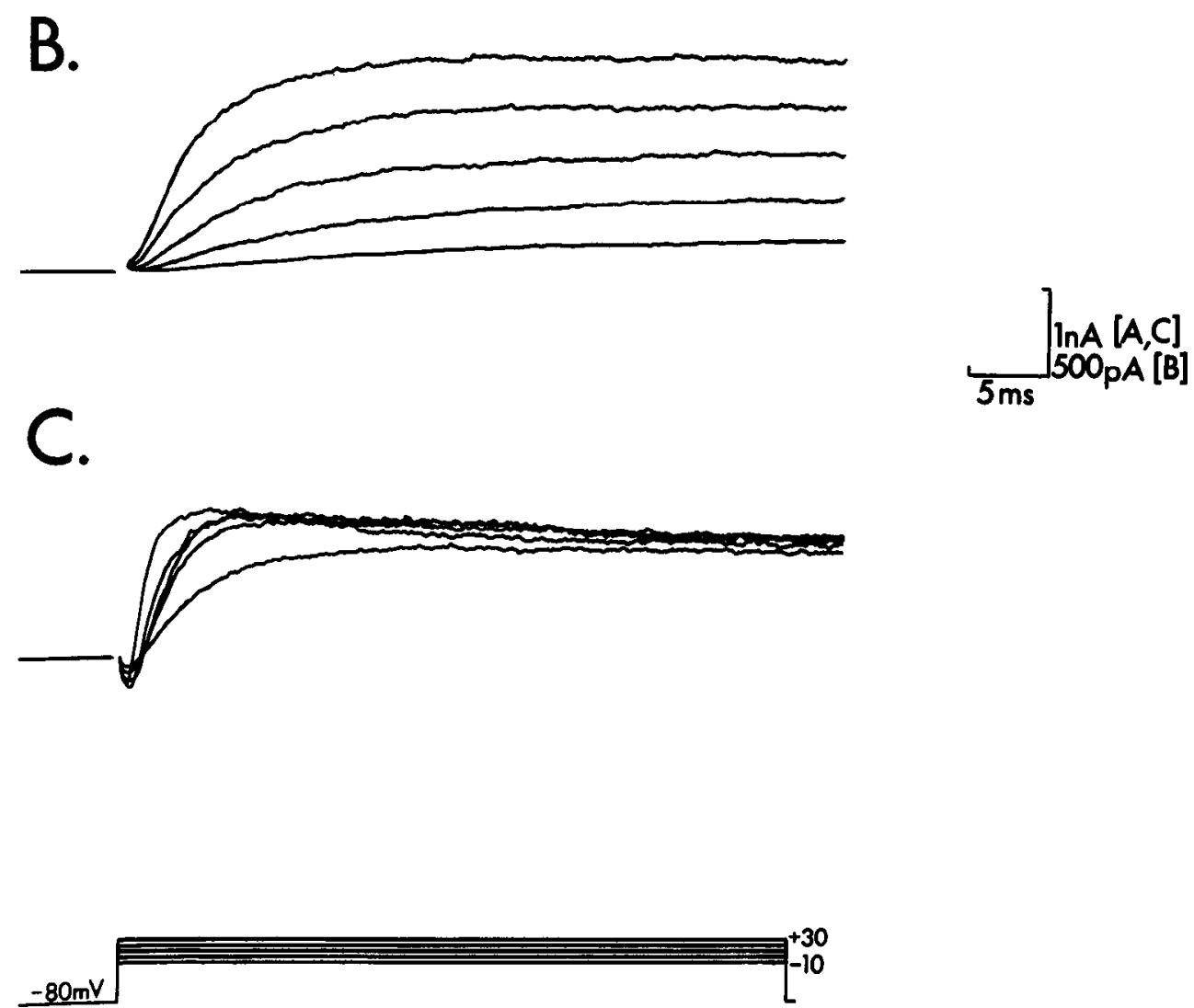

rates of activation and the amplitudes of $\mathrm{I}_{\text {out }}$ were reduced (Fig. $3 B$ ). The $\mathrm{Ca}^{2+}$-dependent component of $\mathrm{I}_{\text {out }}$ (Fig. $3 C$ ), which has been termed $I_{C}$ (Galvan and Sedlmeir, 1984), was determined by subtraction of $\mathrm{I}_{\text {out }}$ waveforms recorded in the presence of $\mathrm{Co}^{2+}$ (Fig. 3B) from those measured in its absence (Fig. 3A). The properties of $\mathrm{I}_{\mathrm{C}}$ are qualitatively similar to those reported previously for adult SCG neurons (Galvan and Sedlmeir, 1984). $I_{C}$ has a time course similar to that of $I_{C a}$ and appears to follow directly the time course of $\mathrm{Ca}^{2+}$ influx. Although we have not examined the properties of $\mathrm{I}_{C}$ quantitatively, $\mathrm{I}_{\mathrm{C}}$ was observed in all E14.5-16.5 $(n=6)$ and E20-neonatal $(n=11)$ SCG cells examined $\leq 24 \mathrm{hr}$ after isolation under the recording conditions described above, and the properties of $\mathrm{I}_{\mathrm{C}}$ were qualitatively similar in these cells. Absolute $I_{c}$ amplitudes were variable, presumably as a result of variations in $\mathrm{I}_{\mathrm{Ca}}$.

After $I_{C}$ is blocked, the waveforms of $I_{\text {out }}$ in neonatal SCG cells ( $\leq 24 \mathrm{hr}$ after isolation), similar to those described previously in mature SCG neurons (Freschi, 1983; Galvan and Sedlmeir, 1984; Belluzzi et al., 1985a), vary with HP (Fig. 4) and appear to comprise two distinct outward current components:
(1) a rapidly activating, transient component, termed $\mathrm{I}_{\mathrm{A}}$ (Hagiwara et al., 1961; Connor and Stevens, 1971a, b; Adams et al., 1980; Segal et al., 1984; Rogawski, 1985) and (2) a slowly activating, sustained component, similar to the delayed rectifier, $I_{K}$ (Adams et al., 1980; Latorre et al., 1984). The differing timeand voltage-dependent properties of $I_{A}$ and $I_{K}$ were exploited to evaluate their respective contributions to the total $\left(\mathrm{Ca}^{2+}\right.$-independent) voltage-activated outward $\mathrm{K}^{+}$currents in developing SCG cells. Peak (which reflects $I_{A}$ ) and plateau (which reflects $I_{K}$ ) outward current amplitudes were measured during depolarizations to potentials between -40 and $+60 \mathrm{mV}$ from an HP of $-80 \mathrm{mV}$. Although the plateau current, i.e., $\mathrm{I}_{\mathrm{K}}$, did not decay significantly during prolonged ( $\geq 200 \mathrm{msec}$ ) depolarizations, preliminary experiments revealed that $I_{K}$ amplitudes were reduced when voltage steps were presented at $\leq 2$-sec intervals. Since these observations suggest that $\mathrm{I}_{\mathrm{K}}$ channels undergo steadystate inactivation over the same potential range that channels open and, in addition, that recovery from steady-state inactivation is slow, voltage steps were presented at $\geq 5$-sec intervals to allow quantitative analyses of $I_{K}$. Normalized current-voltage 

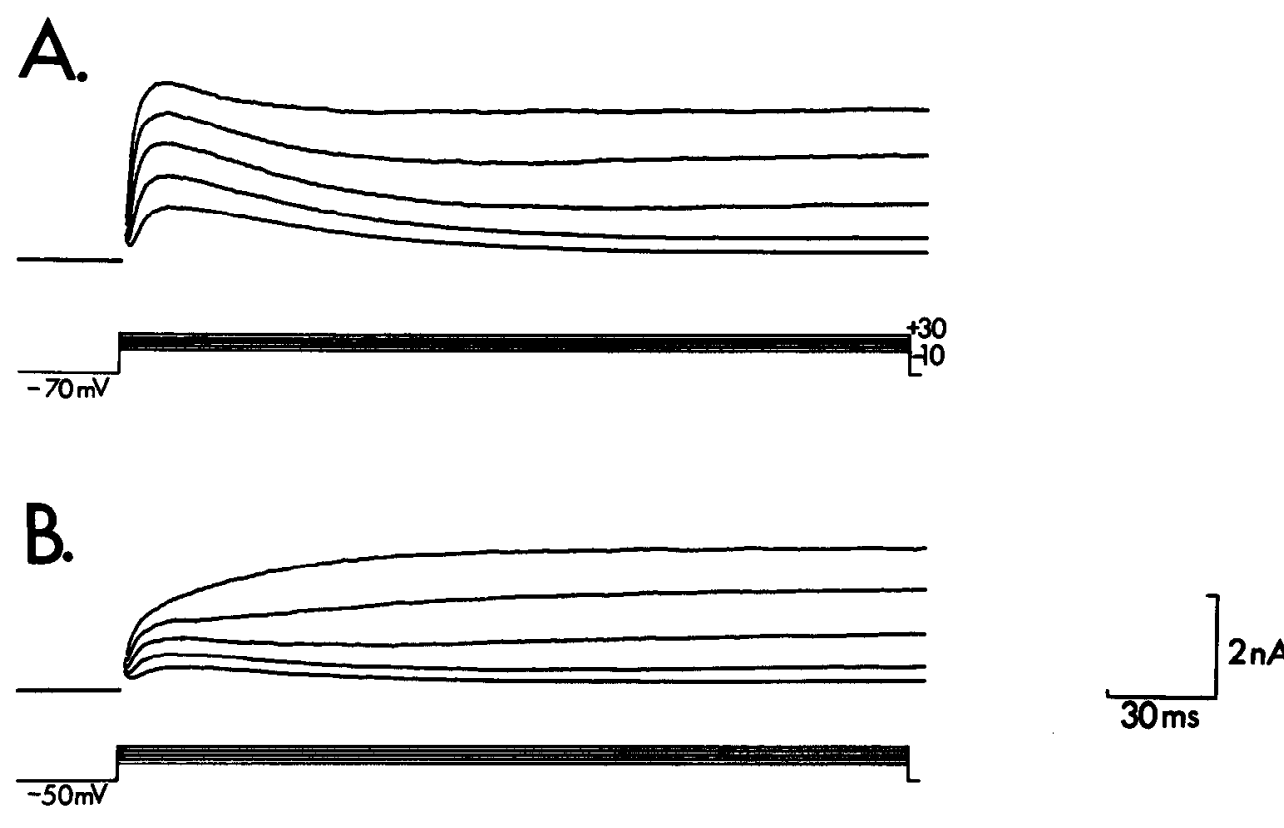

Figure 4. Voltage-gated $\mathrm{Ca}^{2+}$-independent outward $\mathrm{K}^{+}$currents in a neonatal SCG cell. Whole-cell $\mathrm{Ca}^{2+}$-independent $\mathrm{K}^{+}$currents were evoked (at 5 -sec intervals) during $125 \mathrm{msec}$ depolarizations to test potentials between -30 and $+50 \mathrm{mV}$ from HPs of -70 $\mathrm{mV}(A),-50 \mathrm{mV}(B)$, and $-35 \mathrm{mV}$ (C). The bath contained $2 \mu \mathrm{M}$ TTX and $10 \mathrm{mM} \mathrm{Co}^{2+}$ to block $\mathrm{I}_{\mathrm{Na}}, \mathrm{I}_{\mathrm{Ca}}$, and $\mathrm{I}_{\mathrm{C}}$, and the recording pipette contained 140 mм KCl. The voltage-clamp paradigms are indicated below the current records. At more depolarized HPs $(C)$, the evoked currents are dominated by the slower activating, noninactivating $\mathrm{I}_{\mathrm{K}}$. When the cell was held more hyperpolarized $(A, B)$, the fast, transient $\mathrm{I}_{\mathrm{A}}$ was apparent, and the currents measured reflect the sum of $I_{A}$ and $I_{K}$.

relations for $I_{A}$ and $I_{K}$ in E20-neonatal $\leq 24 \mathrm{hr}$ in vitro revealed that the amplitudes of both components increased with increasing depolarization with no apparent saturation over the potential range of -40 to $+60 \mathrm{mV}$ (Nerbonne et al., 1986). Similar results were obtained when currents were evoked from an HP of $-50 \mathrm{mV}$, although, in this case, $\mathrm{I}_{\mathrm{A}}$ amplitudes were markedly reduced, apparently as a result of steady-state inactivation (Nerbonne et al., 1986). The absolute amplitudes of $I_{K}$ and $I_{A}$ in E20-neonatal SCG cells ( $\leq 24 \mathrm{hr}$ in vitro) varied among cells. $I_{A}$ evoked at $+10 \mathrm{mV}$ from an $\mathrm{HP}$ of $-80 \mathrm{mV}$, for example, varied from 0.88 to $3.3 \mathrm{nA}$ (mean $=2.0 \mathrm{nA}$; median $=2.0 \mathrm{nA}$; $n=13$ ), and $\mathrm{I}_{\mathrm{K}}$, during the same step, varied from 0.60 to 2.6 $\mathrm{nA}($ mean $=1.3 ;$ median $=1.2 ; n=13)$. These ranges are smaller than those observed for inward current amplitudes. Absolute $I_{K}$ and $I_{A}$ amplitudes increased in E20-neonatal cells maintained in vitro as the cells increased in size (Table 1), and although mean $I_{K}$ density (Table 3 ) in these cells did not vary markedly, $\mathrm{I}_{\mathrm{A}}$ density decreased (Table 3$)$ significantly $(p<0.001)$ during the first few days after plating. Neither the kinetics nor the voltage-dependences of $I_{A}$ or $I_{K}$ were altered in cells examined at different times after isolation.

Although a $\mathrm{Ca}^{2+}$-dependent component of $\mathrm{I}_{\mathrm{A}}$ has been described in adult SCG neurons (Galvan and Sedlmeir, 1984), it was not clear if a similar conductance pathway is present in E20-neonatal cells. To examine this possibility, $\mathrm{I}_{\mathrm{A}}$ waveforms in the presence and absence of extracellular $\mathrm{Ca}^{2+}$ were measured during depolarizations to potentials between -30 and $-10 \mathrm{mV}$ (where there is little or no activation of $\mathrm{I}_{\mathrm{K}}$ ) from an
HP of $-90 \mathrm{mV}$. Subtraction of these records revealed only inward currents. Since $\mathrm{Ca}^{2+}$ currents evoked during depolarizations to -30 to $-10 \mathrm{mV}$ are small (see Fig. 2), it might be suggested that a $\mathrm{Ca}^{2+}$-dependent component of $\mathrm{I}_{\mathrm{A}}$ (even if present) might not have been revealed in these experiments. Although we cannot eliminate this possibility based on these studies alone, no $\mathrm{Ca}^{2+}$-activated transient outward currents are evident in these cells following intracellular $\mathrm{Ca}^{2+}$ jumps in the presence of the photolabile $\mathrm{Ca}^{2+}$ chelator, Nitr-5 (Gurney et al., 1987).

\begin{tabular}{|c|c|c|c|c|c|}
\hline $\begin{array}{l}\text { Age at } \\
\text { isolation }\end{array}$ & $\begin{array}{l}\text { Time } \\
\text { in vitro }\end{array}$ & $\begin{array}{l}\mathrm{I}_{\mathrm{A}} \text { density }{ }^{a, b} \\
\left(\mathrm{pA} / \mu \mathrm{m}^{2}\right)\end{array}$ & $n$ & $\begin{array}{l}\mathrm{I}_{\mathrm{K}} \text { density }{ }^{a, b} \\
\left(\mathrm{pA} / \mu \mathrm{m}^{2}\right)\end{array}$ & $n$ \\
\hline \multirow[t]{3}{*}{ E20-neonatal } & $\leq 24 \mathrm{hr}$ & $1.00 \pm 0.27^{c}$ & 13 & $0.67 \pm 0.25$ & 13 \\
\hline & $48-96 \mathrm{hr}$ & $0.55 \pm 0.24^{c}$ & 14 & $0.60 \pm 0.42$ & 14 \\
\hline & $5-6 d$ & $0.59 \pm 0.14$ & 8 & $0.78 \pm 0.25$ & 8 \\
\hline \multirow[t]{3}{*}{ E14.5-16.5 } & $\leq 24 \mathrm{hr}$ & & & $0.51 \pm 0.35$ & 44 \\
\hline & $48-96 \mathrm{hr}$ & $(1.54)^{d}$ & & $0.69 \pm 0.54$ & 13 \\
\hline & $5-8 d$ & $0.59 \pm 0.38$ & 18 & $0.55 \pm 0.36$ & 18 \\
\hline
\end{tabular}

${ }^{a}$ Determined during depolarizations to $+10 \mathrm{mV}$ from an $\mathrm{HP}$ of $-80 \mathrm{mV}$.

${ }^{b}$ Values are mean $\pm \mathrm{SD}$.

c There was a significant $(p<0.001)$ decrease in mean $\mathrm{I}_{\mathrm{A}}$ density in E20-neonatal cells examined $48-96 \mathrm{hr}$ after isolation compared to that measured in cells $\leq 24$ $\mathrm{hr}$ in vitro.

${ }^{d}$ A peak outward current (corresponding to $I_{A}$ ) was measured in 3 of 13 cells examined; this value reflects the average of those 3 cells. 
Figure 5. Variations in $\mathrm{I}_{\mathrm{A}}$ in developing SCG neurons. Whole-cell $\mathrm{Ca}^{2+}-$ independent $\mathrm{K}^{+}$currents, evoked during depolarizations from HPs of -80 $\mathrm{mV}$ (left panels) and $-50 \mathrm{mV}$ (right panels), were measured as described in the legend of Figure 4. A, Outward current waveforms evoked from HPs of -80 and $-50 \mathrm{mV}$ in an E14.5 SCG neuron $\approx 6 \mathrm{hr}$ after plating are indistinguishable (compare left and right panels), suggesting that $I_{A}$ was not present in this cell. Similar results were obtained in all cells $(n=44)$ isolated at E14.5-16.5 and examined $\leq 24 \mathrm{hr}$ in vitro. $B$, When E14.5-16.5 cells were examined after several days in vitro, outward current waveforms varied with the $\mathrm{HP}(B)$, and $\mathrm{I}_{\mathrm{A}}$ was evident during depolarizations from $-80 \mathrm{mV}$ (left panel). Similar results were obtained in all $(n=18)$ E14.5-16.5 SCG cells examined 5-8 days after isolation.
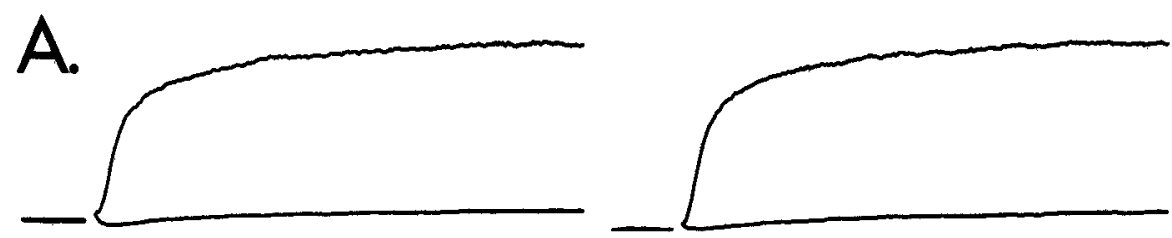

B.
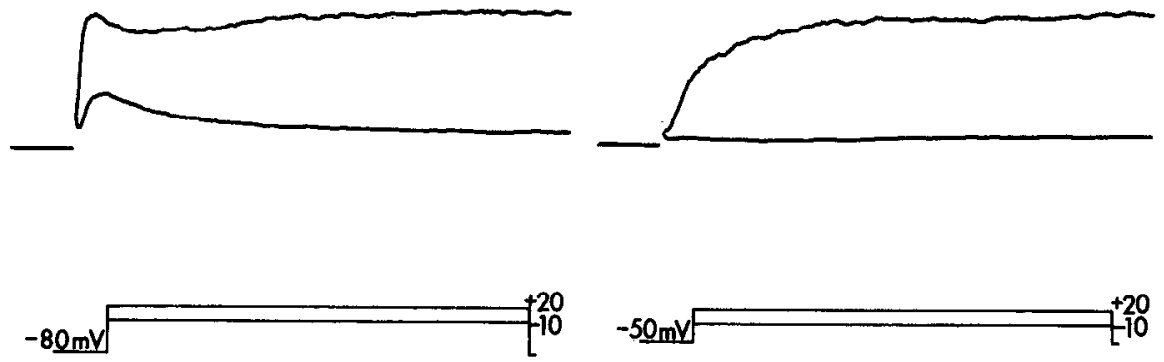

Substantial variations in $I_{\text {out }}$ waveforms were observed in E16.5-18.5 SCG cells. In only $\approx 50 \%$ of the cells was $\mathrm{I}_{\mathrm{A}}$ evident. In addition, when E14.5-16.5 SCG cells $(n=44)$ were examined $\leq 24 \mathrm{hr}$ after dissociation, $\mathrm{I}_{\mathrm{A}}$ was not evident, and the waveforms of $\mathrm{I}_{\text {out }}$ evoked during depolarizations from HPs of -50 and -80 $\mathrm{mV}$ were indistinguishable (Fig. 5A). When SCG cells isolated at E14.5-16.5 were examined after 5-7 days in vitro, in contrast, the waveforms of $I_{\text {out }}$ varied as a function of $H P$, and $I_{A}$ was evident on depolarizations from hyperpolarized potentials (Fig. $5 B$ ). These observations suggested that $I_{A}$ was not present in SCG neurons isolated at E14.5-16.5 and that $I_{A}$ developed in these cells if maintained in vitro for several days. Alternatively, if the amplitudes of $I_{A}$ were small relative to $I_{K}$, it might be that $I_{A}$ was obscured (rather than absent) in E14.5-16.5 SCG cells. In order to evaluate this possibility, the rates of outward current activation (see Methods) evoked from an HP of $-80 \mathrm{mV}$ were

Table 4. Rate constants for outward current activation in developing SCG neurons

\begin{tabular}{llcc}
$\begin{array}{l}\text { Test } \\
\text { potential } \\
(\mathrm{mV})\end{array}$ & $\begin{array}{l}k\left(\mathrm{sec}^{-1}\right)^{a, b} \\
\text { Neonatal } \\
\leq 48 \mathrm{hr}\end{array}$ & $\begin{array}{l}\mathrm{E} 14.5-16.5 \\
\leq 48 \mathrm{hr} \\
(n=16)\end{array}$ & $\begin{array}{l}14.5-16.5 \\
5-8 \text { days } \\
(n=17)\end{array}$ \\
\hline-20 & $316 \pm 28$ & - & - \\
-10 & $444 \pm 22$ & $82 \pm 8$ & $346 \pm 34$ \\
0 & $530 \pm 26$ & $101 \pm 11$ & $446 \pm 31$ \\
10 & $631 \pm 29$ & $114 \pm 12$ & $583 \pm 33$ \\
20 & $693 \pm 33$ & $134 \pm 12$ & $666 \pm 46$ \\
30 & $792 \pm 63$ & $142 \pm 13$ & $814 \pm 48$ \\
40 & $899 \pm 104$ & $155 \pm 13$ & $878 \pm 71$ \\
50 & $972 \pm 105$ & $166 \pm 15$ & $1010 \pm 90$
\end{tabular}

${ }^{a} k$ values were measured (see Materials and Methods) for currents evoked from an HP of $-80 \mathrm{mV}$.

${ }^{b}$ Values are mean \pm SEM. examined in E14.5-16.5 and E20-neonatal SCG cells within 24 $\mathrm{hr}$ of isolation and as a function of time in vitro. As $\mathrm{I}_{\mathrm{K}}$ and $\mathrm{I}_{\mathrm{A}}$ activation rates differ by approximately an order of magnitude (Fig. 4), the apparent rates of total outward current activation should vary as a function of the relative contributions of $I_{A}$ and $\mathrm{I}_{\mathrm{K}}$. Analyses of the rates of outward current activation in E20 neonatal SCG cells revealed that the rate constants were voltagedependent (Nerbonne et al., 1986), increasing with increasing depolarization (Table 4). Similar results were obtained for E18.520 SCG cells, and no significant differences in activation rate constants were evident in these cells studied up to $\approx 3$ weeks in vitro (not shown). Analyses of the rates of $\mathrm{I}_{\text {out }}$ activation in E14.5-16.5 SCG cells $\leq 24 \mathrm{hr}$ after isolation, in contrast, revealed rate constants $\approx 6$-fold smaller (Table 4 ). These observations are consistent with the suggestion that $I_{A}$ is absent in SCG cells isolated at E14.5-16.5. The rates of $\mathrm{I}_{\text {out }}$ activation in these cells, therefore, are determined by $\mathrm{I}_{\mathrm{K}}$. When E14.5-16.5 $\mathrm{SCG}$ cells were examined after $\approx 1$ week in vitro, the rate constants for outward current activation were increased $\approx 6$-fold and were similar to those measured in neonatal cells $\leq 24 \mathrm{hr}$ in vitro (Table 4), suggesting that $I_{A}$ was now functional in these cells.

In contrast to the observed variations in $\mathrm{I}_{\mathrm{A}}$ in developing $\mathrm{SCG}$ cells, there were no measurable differences in the voltage-dependent properties of $I_{K}$ among SCG neurons isolated at different developmental (E14.5-neonatal) times (Fig. 6A) or for embryonic cells maintained in vitro (Fig. $6 B$ ). The kinetic properties of $I_{K}$ (Table 4) also were indistinguishable (Nerbonne et al., 1986). The absolute amplitudes of $I_{K}$ in E14.5-16.5 SCG cells $\leq 24 \mathrm{hr}$ in vitro were similar, although somewhat more variable, than those measured in E20-neonatal cells (see above). $I_{K}$ amplitudes in E14.5-16.5 cells examined $\leq 24 \mathrm{hr}$ after isolation varied over the range 0.10 to $2.2 \mathrm{nA}$ (mean $=0.45 \mathrm{nA}$; median $=0.30 \mathrm{nA} ; n=44$ ). Nevertheless, $\mathrm{I}_{\mathrm{K}}$ densities in these cells were not significantly different from those measured in E20-neonatal cells (Table 3) and, in addition, did not vary sig- 


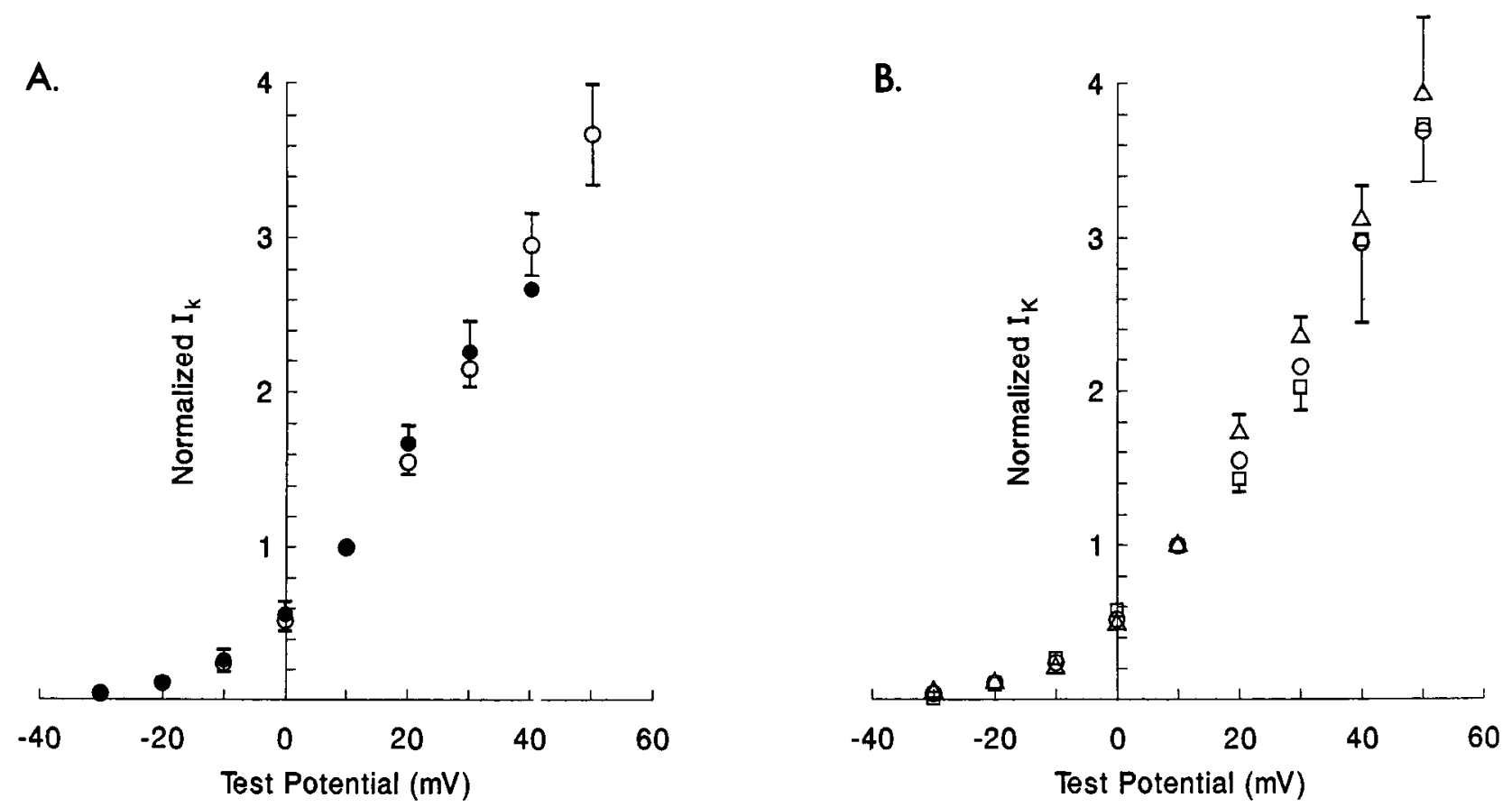

Figure 6. Normalized current-voltage relation for $I_{K}$ in developing SCG neurons. Outward currents were evoked during depolarizations from an $\mathrm{HP}$ of $-80 \mathrm{mV}$, as described in the legend of Figure 4 . The amplitudes of the currents remaining at 125 msec (i.e., the plateau) were measured in individual cells and normalized to the currents evoked at $+10 \mathrm{mV}$ in the same cell. $A$, Mean normalized current-voltage relations for $\mathrm{I}_{\mathrm{K}}$ in $\mathrm{E} 14.5-$ $16.5(0, n=44)$ and E20-neonatal $(\bullet, n=13)$ SCG cells $\leq 24 \mathrm{hr}$ after isolation are indistinguishable. $B$, Similar results were obtained for cells examined at various times during development in vitro. The normalized current-voltage relations for $I_{\mathrm{K}}$ in $\mathrm{E} 14.5-16.5 \mathrm{SCG}$ cells $\leq 24 \mathrm{hr}(\mathrm{O}, n=$ $44), 48-96 \mathrm{hr}(\square, n=13)$, and 5-8 days $(\Delta, n=18)$ in vitro superimpose.

nificantly in cells maintained for varying times in vitro (Table 3). Taken together, these observations reveal no evidence for any significant developmental changes in $I_{K}$ in SCG neurons.

\section{Resting membrane potentials and action potentials}

With normal bath solution and $140 \mathrm{mM} \mathrm{KCl}$ in the recording pipettes, RPs and AP waveforms were measured in isolated SCG cells. In early and late embryonic SCG cells, RPs (Table 5) were similar to those measured previously using microelectrode techniques in adult (Galvan and Sedlmeir, 1984; Belluzzi et al., 1985a) and long-term cultured neonatal (Higgins and Burton, 1982; Freschi, 1983) SCG neurons. For E20 SCG cells examined $\leq 24 \mathrm{hr}$ after isolation, RPs varied over a range of $\approx 30 \mathrm{mV}$, with a mean $( \pm S D)$ value of $-53 \pm 8 \mathrm{mV}$ (Table 5). No significant differences in RPs were evident among cells evaluated over approximately 1 week in vitro (Table 5). As cells were examined within hours of isolation, it is assumed that the data reflect the RPs of cells in vivo at the time of dissociation.

In E20-neonatal cells, APs evoked by brief depolarizing current injections (via the recording pipettes) were similar to those described previously in adult (Galvan and Sedlmeir, 1984; Belluzzi et al., 1985a) and long-term cultured neonatal (Higgins and Burton, 1982) SCG neurons. APs (Fig. 7A) were characterized by fast activation, somewhat slower repolarization, and prolonged afterhyperpolarization. In general, AP waveforms were quite stereotyped, although differences in (AP) amplitudes and durations were observed that appeared to correlate with differences in RPs. AP waveforms were similar in cells examined 37 days after isolation (not shown). As reported previously for mature SCG cells (Higgins and Burton, 1982), E20-neonatal SCG cells could be stimulated to fire APs repetitively during prolonged current injections. Maximal firing frequencies were observed in the range of 15-30 Hz. In the presence of TTX (1 $\mu \mathrm{M})$, it was more difficult to evoke APs, unless outward $\mathrm{K}^{+}$ currents were also partially suppressed. APs (when evoked) were slower to rise, reduced in amplitude, and, in some cells, prolonged. When $\mathrm{Ca}^{2+}$ influx was blocked by the addition of $\mathrm{Co}^{2+}$ to the bath in the absence of TTX, in contrast, neither the rising phases, the peak amplitudes, nor the currents required to evoke APs were significantly affected, although AP afterhyperpolarizations were eliminated or markedly reduced. These results suggest that both $\mathrm{Na}^{+}$and $\mathrm{Ca}^{2+}$ influx are important in determining AP waveforms in developing, as in mature (Higgins and Burton, 1982; Freschi, 1983; Galvan and Sedlmeir, 1984; Belluzzi et al., 1985b; Kawai and Watanabe, 1986; Marrion et al., 1987), SCG neurons.

The waveforms of APs in $\leq$ E16.5 SCG cells examined $\leq 24$ $\mathrm{hr}$ after isolation were similar (although not identical) to those described above. The rising phases of APs in E16 and E20 SCG cells, for example, were indistinguishable, although the initial phase of AP repolarization was slower in E16 cells, and APs

Table 5. Resting membrane potentials in developing SCG neurons

\begin{tabular}{lllll}
$\begin{array}{l}\text { Age at } \\
\text { isolation }\end{array}$ & $\begin{array}{l}\text { Time } \\
\text { in vitra }\end{array}$ & $\mathrm{RP}(\mathrm{mV})^{a}$ & Range (mV) & $n$ \\
\hline E20 & $\leq 24 \mathrm{hr}$ & $-53 \pm 8$ & -38 to -66 & 24 \\
& $24-48 \mathrm{hr}$ & $-53 \pm 9$ & -40 to -68 & 23 \\
& $48-72 \mathrm{hr}$ & $-55 \pm 11$ & -35 to -74 & 18 \\
& $4-5 \mathrm{~d}$ & $-53 \pm 8$ & -32 to -68 & 25 \\
E16 & $\leq 24 \mathrm{hr}$ & $-50 \pm 10$ & -35 to -70 & 19 \\
& $4-6 \mathrm{~d}$ & $-53 \pm 8$ & -38 to -70 & 18 \\
\hline
\end{tabular}

${ }^{a}$ Values are mean $\pm \mathrm{SD}$. 


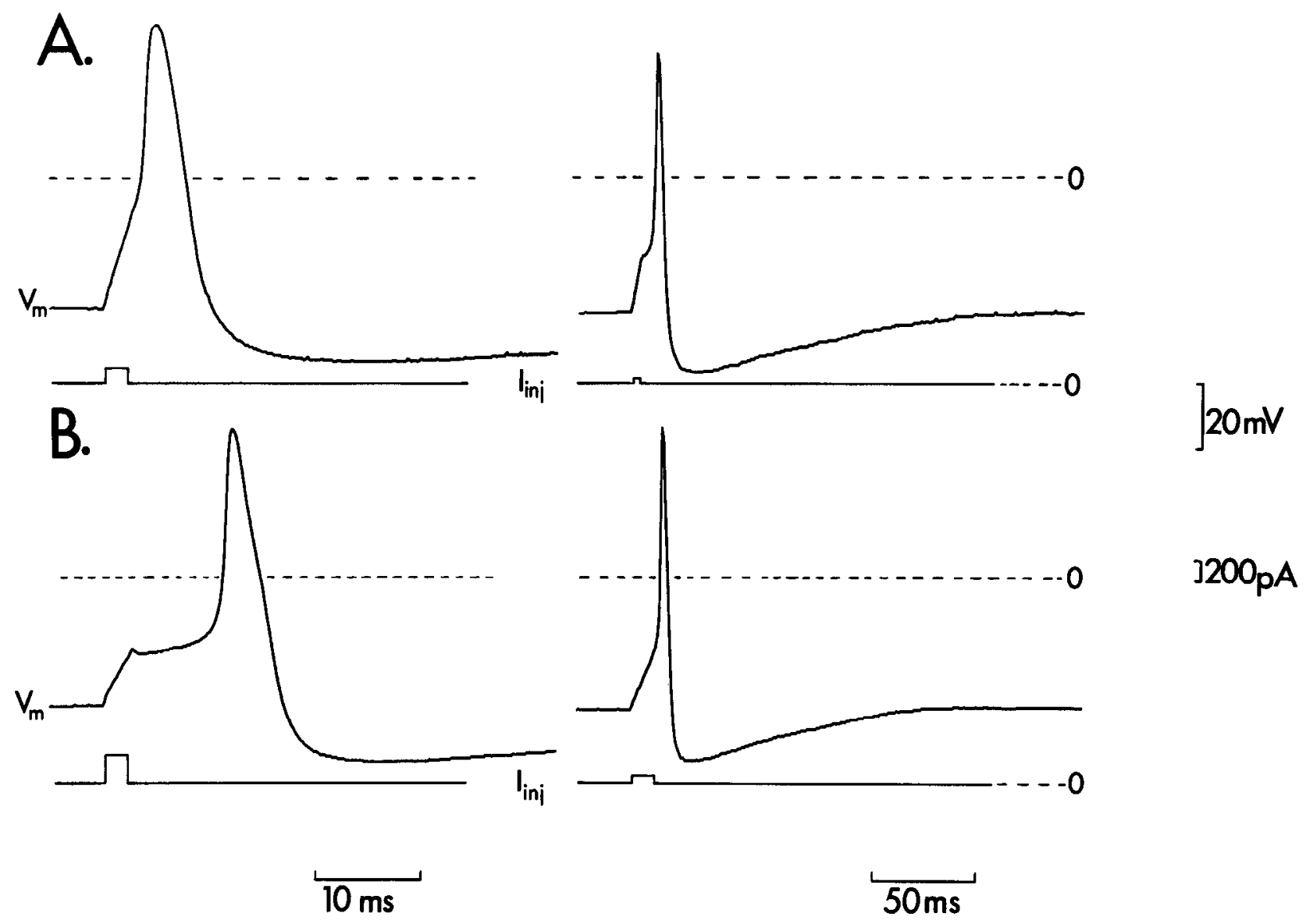

Figure 7. AP waveforms in developing SCG neurons. Whole-cell APs in dissociated E16 $(A)$ and E20 $(B)$ SCG neurons $\approx 20 \mathrm{hr}$ after isolation. Both cells had RPs of $\approx-52 \mathrm{mV}$. APs, evoked at 10 -sec intervals by depolarizing current pulses delivered via the patch pipettes, were recorded on different time scales in the left and right panels of $A, B$. The zero potential level is indicated by the dashed lines. For the E16 SCG neuron ( $A$, left panel), a $2 \mathrm{msec}, 100 \mathrm{pA}$ current pulse evoked an AP with an $\mathrm{APD}_{50}$ (see text) of 4.1 msec. For the E20 cell ( $B$, left panel), in contrast, a 2 msec, $200 \mathrm{pA}$ current pulse evoked an $\mathrm{AP}$ with an $\mathrm{APD}_{\mathrm{s} 0}$ of $2.7 \mathrm{msec}$.

were somewhat broader (Fig. 7A). Comparison of AP durations in E16 and E20 SCG cells $\leq 24 \mathrm{hr}$ after isolation, in fact, revealed that the time required for $50 \%\left(\mathrm{APD}_{50}\right)$ and $90 \%\left(\mathrm{APD}_{90}\right)$ repolarization to the RP were significantly $(p<0.001)$ longer for $\mathrm{E} 16$ cells. $\mathrm{APD}_{50}$ (mean $\pm \mathrm{SD}$ ) values, for example, were $4.6 \pm 1.7$ and $3.1 \pm 0.4 \mathrm{msec}$ for $\mathrm{E} 16(n=15)$ and $\mathrm{E} 20(n=$ 18) SCG cells, respectively. In addition, it is of interest to note that significantly $(p<0.001)$ smaller currents were required to evoke APs in E16 than in E20 SCG cells. During brief $(3 \mathrm{msec})$ depolarizing current injections, the minimal current (mean \pm SD) required to evoke APs in E16 and E20 SCG cells $\leq 24 \mathrm{hr}$ in vitro was $135 \pm 44(n=10)$ and $241 \pm 76(n=14) \mathrm{pA}$, respectively. Although it might be suggested that this difference is attributable to differences in cell input resistances, this possibility seems unlikely, since input resistances (mean $\pm \mathrm{SD}$ ) in E16 and E20 SCG cells examined $\leq 24 \mathrm{hr}$ after isolation were $1.73 \pm 0.86 \mathrm{G} \Omega(n=13)$ and $1.45 \pm 0.83 \mathrm{G} \Omega(n=11)$, respectively. These values are not significantly different. That smaller currents are required to evoke APs in E14.5-16.5 SCG cells seems likely to reflect the absence of $I_{A}$ in these cells. Because $I_{A}$ activates rapidly on membrane depolarization, this conductance pathway is expected to counter depolarization-activated increases in inward (mostly $\mathrm{Na}^{+}$) currents. In the absence of $I_{A}$, therefore, cells would be expected to be more excitable, i.e., smaller currents should bring a cell to threshold when $I_{A}$ is functional.

As previously demonstrated in mature SCG cells (Belluzzi et al., 1985b), marked changes in AP waveforms in late embryonic and neonatal SCG cells were also observed as a function of membrane potential (Fig. 8). It seems unlikely that variations in RPs account for the differences in AP waveforms in E16 and E20 SCG cells (Fig. 7), since no significant differences in RPs were observed among cells isolated at E16 and E20 or in SCG cells maintained for varying times in vitro (Table 5). In addition, the cells in Figure 7 both had RPs of $\approx-52 \mathrm{mV}$. Nevertheless, AP waveforms evoked from rest in E16 SCG cells do resemble those elicited in older cells from more depolarized membrane potentials.

Previously, based on variations in AP durations with membrane potential, it was proposed (Belluzzi et al., 1985a) that $\mathrm{I}_{\mathrm{A}}$, rather than other voltage- $\left(\mathrm{I}_{\mathrm{K}}\right)$ or $\mathrm{Ca}^{2+-}\left(\mathrm{I}_{\mathrm{C}}\right)$ dependent $\mathrm{K}^{+}$currents, underlies AP repolarization in SCG neurons. According to this model, AP durations at different membrane potentials are determined by the (variable) contribution of $I_{A}$. At more depolarized membrane potentials, APs are broader as $I_{A}$ channels undergo steady-state inactivation, whereas at more hyperpolarized membrane potentials, APs are shortened as steadystate inactivation of $I_{A}$ channels is removed (Belluzzi et al., 

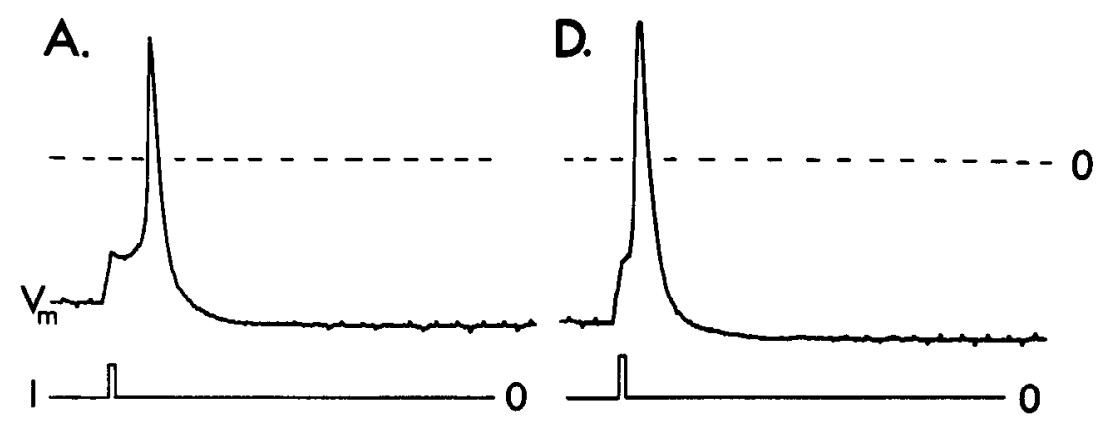
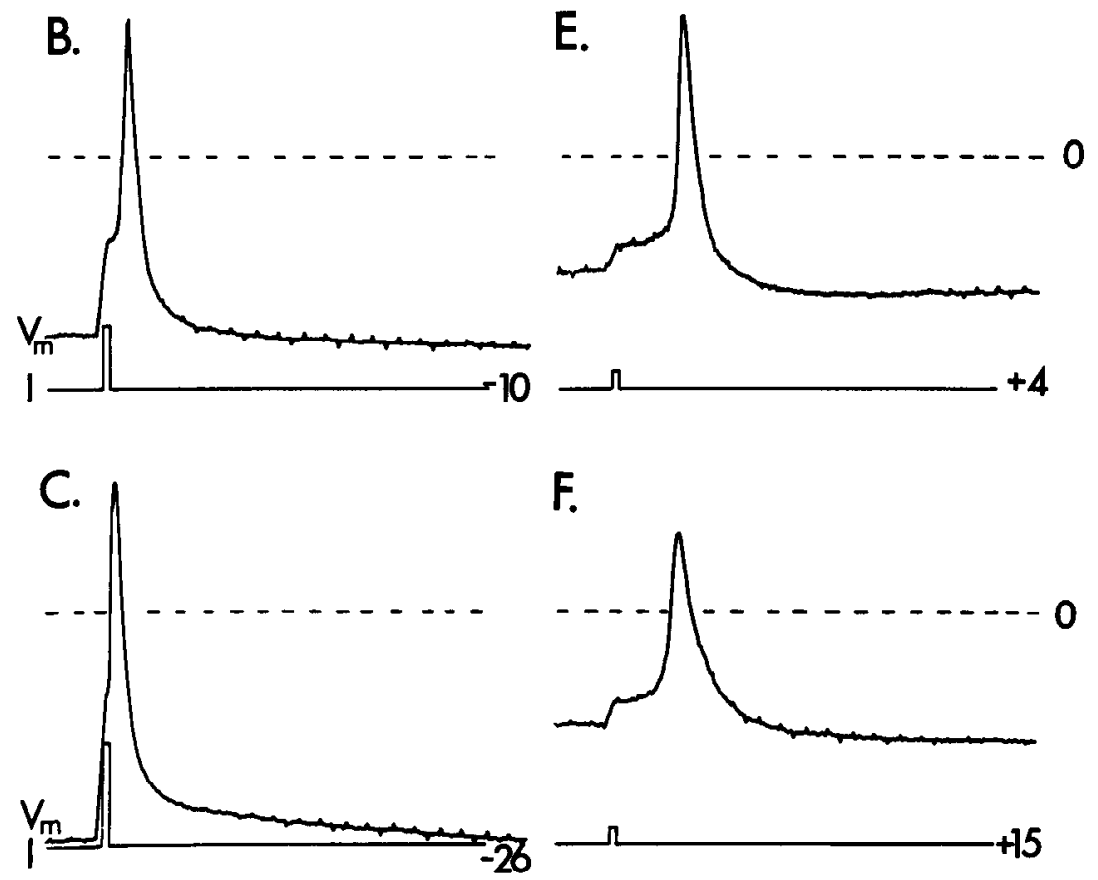

\section{] $20 \mathrm{mV}$}

]200pA
Figure 8. Variations in AP waveforms with membrane potential in an E20 SCG neuron. Recording conditions were as in Figure 7, except that the membrane potential of this ccll was varied by injecting hyperpolarizing $(B$, $C)$ or depolarizing $(E, F)$ current. The amplitudes of the DC currents injected are indicated on the right of the current records. The zero current records $(A, D)$ reflect the RP $(-45 \mathrm{mV})$ of this cell. The zero potential is indicated by the dashed line. The cell was hyperpolarized to $-57 \mathrm{mV}$ in $B$ and $-72 \mathrm{mV}$ in $C$ and depolarized to $-38 \mathrm{mV}(E)$ and $-34 \mathrm{mV}(F)$ before depolarizing current injections that evoked APs. Similar variations in AP waveforms were observed in all E20 SCG cells $(n=26)$ examined. 1985a). The variations in AP waveforms as a function of membrane potential observed here (Fig. 8) are consistent with the predictions of this model. If $\mathrm{I}_{\mathrm{A}}$ plays this role in SCG neurons, its absence in $\leq \mathrm{E} 16.5$ cells could account for the broadened APs in these cells (Fig. 7).

In an attempt to evaluate directly the role of $I_{A}$ in AP repolarization, the effects of 4-AP on AP waveforms in E20 SCG neurons were examined, as 4-AP has been suggested to suppress $\mathrm{I}_{\mathrm{A}}$ preferentially in some cells (Thompson, 1977; Adams et al., 1980; Segal et al., 1984; Rogawski, 1985). Consistent with previous observations (McAffee and Yarowsky, 1979), brief puffer applications of 4-AP (1-3 mM) resulted in AP prolongation (Fig. $9 A$ ). In this cell, the $\mathrm{APD}_{50}$ increased from 3 to $5.2 \mathrm{msec}$ following 4-AP application. These observations support a role for $I_{A}$ in AP repolarization in SCG cells. In $\approx 30 \%$ of the cells examined, however, 4-AP also reduced afterhyperpolarization amplitudes (Fig. 9A), suggesting that 4-AP has effects on $\mathrm{K}^{+}$ currents in addition to $\mathrm{I}_{\mathrm{A}}$. This was confirmed in voltage-clamp experiments (Fig. 9B), since puffer applications of 4-AP (1-3 $\mathrm{mM}$ ) also partially suppressed $\mathrm{I}_{\mathrm{K}}$. These observations complicate interpretation of the effects of 4-AP on the AP. As $I_{K}$ almost certainly contributes to AP repolarization, the broadening of the AP (Fig. $9 A$ ) by 4-AP may be partially attributed to suppression of $I_{K}$ (in addition to $I_{A}$ ). Unfortunately, this possibility is difficult to examine in any detail in the absence of more specific blockers of $I_{K}$ and $I_{A}$. Perhaps as more specific $K^{+}$channel blockers or toxins (Pappone and Cahalan, 1987) become available, it will be possible to delineate the precise role(s) of $\mathrm{I}_{\mathrm{A}}$ and $\mathrm{I}_{\mathrm{K}}$ in AP repolarization in $S C G$ neurons.

\section{Discussion}

The results presented here demonstrate that electrically excitable membrane properties in neonatal and late embryonic ( $\geq$ E18.5) rat SCG neurons are similar to those described previously in mature SCG cells (Freschi, 1983; Galvan and Sedlmeir, 1984; Belluzzi et al., 1985a, b; Marrion et al., 1987). Electrophysiological recordings were obtained within hours of cell dissociations and are assumed to reflect the in vivo membrane properties of these cells at the time of isolation. When these cells were examined after varying times in vitro, the absolute amplitudes of voltage-gated inward and outward currents were increased, although no significant differences in the timeor voltage-dependent properties of the currents and no measurable changes in RPs or AP waveforms were observed. Taken 

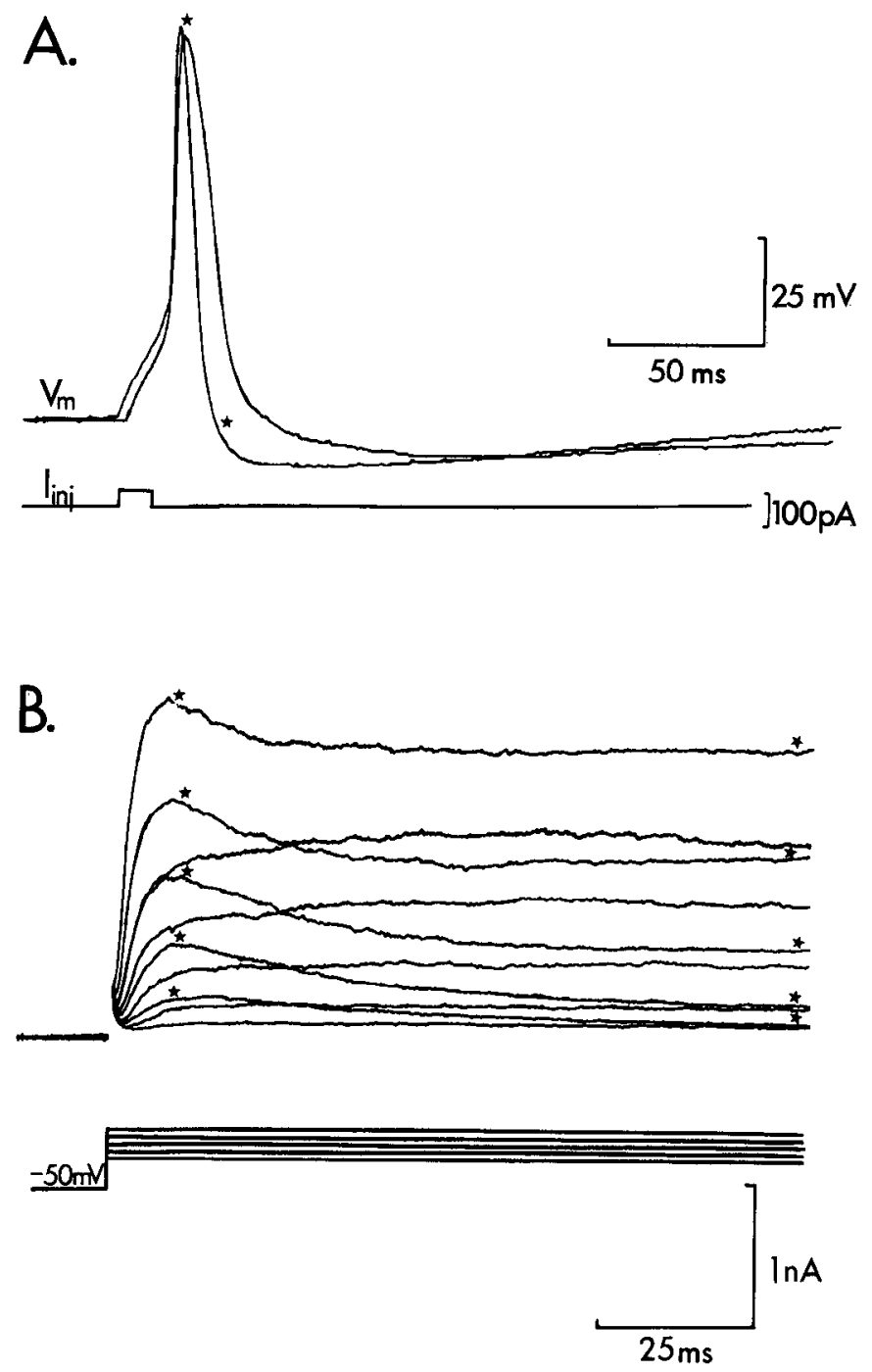

Figure 9. Effects of 4-AP on AP waveforms and voltage-gated $\mathrm{K}^{+}$ currents in E20 SCG neurons. A, APs were measured as described in the legend of Figure 7. This cell had an RP of $\approx-65 \mathrm{mV}$. The control AP, recorded before application of 4-AP, is indicated by the asterisk. Following puffer application of ( $3 \mathrm{~mm}) 4-\mathrm{AP}$ for $30 \mathrm{sec}$, the AP was broadened. Similar results were obtained in 6 other E20 SCG cells. $B$, Outward currents, evoked during depolarizations to potentials between -10 and $+40 \mathrm{mV}$ from an $\mathrm{HP}$ of $-50 \mathrm{mV}$ were measured as described in the legend of Figure 4. Control $\mathrm{K}^{+}$currents are indicated by the asterisks. Following a 30-sec application of (3 mM) 4-AP, the peak of the outward current is less evident, suggesting substantial block of $I_{A}$. In addition, attenuation of the plateau current $\left(I_{K}\right)$ also is observed. Similar results were obtained in 8 other E20 SCG neurons, in which puffer applications of $1-3 \mathrm{~mm} 4$-AP resulted in $\geq 50 \%$ suppression of the peak outward $\mathrm{K}^{+}$current.

together, these observations suggest that SCG neurons are electrophysiologically mature well before birth. Although this conclusion is in apparent conflict with at lease one previous study (Smith et al., 1982), more recent work (Rubin, 1985a, b, c) suggests that the SCG is well developed early in embryonic life: Axon outgrowth from the SCG was evident at E14.5 (Rubin, 1985a), dendritic outgrowth was observed at E15.5 (Rubin, $1985 \mathrm{~b}$ ), and, perhaps most interesting, synaptic transmission could be measured as early as E14.5 (Rubin, 1985c).

In spite of the increases in absolute current amplitudes, mean $I_{A}$ (Table 3) and $I_{C_{a}}$ (Table 2) densities appeared to decrease in
E20-neonatal cells during the first 4 days in vitro. Owing to the difficulties associated with maintaining adequate spatial control of the membrane voltage in cells that have elaborated processes, however, it might be suggested that these observations should be interpreted with some caution. Poor voltage control could result in underestimates of current amplitudes and thereby result in apparent reductions in current densities. Although we cannot eliminate this possibility unequivocally, it should be noted that no significant variations in mean $I_{K}$ density (Table 3 ) were evident in cells examined at similar times after isolation, and, in addition, no further decreases in $\mathrm{I}_{\mathrm{Ca}}$ or $\mathrm{I}_{\mathrm{A}}$ densities were observed in E20-neonatal SCG cells examined after $\approx 4$ days in vitro (Tables 2 and 3 ) in spite of continued increases in cell size (Table 1). As a result, we favor the interpretation that the results reflect developmental decreases in $\mathrm{I}_{\mathrm{Ca}}$ and $\mathrm{I}_{\mathrm{A}}$ densities in these cells. This interpretation (at least for $\mathrm{I}_{\mathrm{Ca}}$ ) is supported by the observation that mean peak $\mathrm{I}_{\mathrm{Ca}}$ density measured in E14.5-16.5 SCG cells $\leq 24 \mathrm{hr}$ after isolation was significantly higher (Table 2) than in E20-neonatal cells. In addition, mean $\mathrm{I}_{\mathrm{Ca}}$ density in E14.5-16.5 cells also decreased over time in vitro.

When compared with the results obtained in late embryonic and neonatal SCG cells, several additional differences in excitable membrane properties were evident in E14.5-16.5 SCG neurons examined within the first $24 \mathrm{hr}$ after isolation. In particular, although other voltage-activated currents were measured, $I_{A}$ was not evident in these cells. In addition, although input resistances were similar, smaller currents were required to evoke APs and APs were broader in these cells than in $\geq E 18.5$ $\mathrm{SCG}$ cells. Although it seems likely that $\mathrm{I}_{\mathrm{A}}$ was absent in vivo at the time the cells were dissociated from the ganglia, it might also be argued that the cells were damaged during the isolation procedure, resulting in the loss of $I_{A}$ channels. Although we have no direct evidence on this point, we think this possibility unlikely for several reasons. First, other voltage-activated currents, e.g., $I_{N a}, I_{C a}$, and $I_{K}$, were readily measured in these cells, and the time- and voltage-dependent properties of these currents were indistinguishable from those measured in $\geq E 18.5$ SCG cells. In addition, when SCG cells isolated at E14.5-16.5 were evaluated after $\approx 5-8$ days in vitro, $\mathrm{I}_{\mathrm{A}}$ was present. The appearance of $\mathrm{I}_{\mathrm{A}}$ in vitro, therefore, paralleled the apparent time course of development of $I_{A}$ in vivo. As a result, we favor the interpretation that $I_{A}$ was not measured in E14.5-16.5 SCG neurons at the time of isolation because this conductance pathway had not yet developed in these cells in vivo.

In some molluscan neurons (Connor and Stevens, 1971a, b), $I_{A}$ is involved in regulating repetitive firing. It seems unlikely that this is the primary function of $I_{A}$ in rat $S C G$ neurons for several reasons. For example, in response to prolonged current injections, SCG neurons displayed a very limited range of firing rates with maximal frequencies of $\leq 30 \mathrm{~Hz}$. Repetitive firing, therefore, does not seem to be a prominent feature of SCG neurons. In addition, the observation that firing frequencies in E14.5-16.5 SCG cells (in which $I_{A}$ was not apparent) were not significantly different from those in late embryonic and neonatal cells implies that neither the ability to fire APs repetitively nor the maximal firing frequency can be influenced significantly by the presence or the functioning of $I_{A}$. It has been suggested (Belluzzi et al., 1985a) that $I_{A}$, rather than $I_{K}$ or $I_{C}$, is the $K^{+}$ conductance pathway primarily responsible for AP repolarization in mammalian sympathetic neurons. If this were the case, the absence or suppression of $I_{A}$ should be clearly reflected in the AP waveform. APs would be expected to be prolonged rel- 
ative to APs evoked when $I_{A}$ is functional. The findings that APs were broader in the presence of 4-AP and at depolarized membrane potentials, where $I_{A}$ is inactivated, are consistent with this postulated role for $I_{A}$ in AP repolarization. Furthermore, the observations that (1) APs were broader in E14.5-16.5 (which lack $I_{A}$ ) than in $\geq$ E18.5 SCG cells $\leq 24 \mathrm{hr}$ in vitro, (2) APs in E14.5-16.5 SCG cells maintained for several days in vitro repolarizcd morc rapidly than APs in freshly isolated cells, and, (3) developmental changes in AP waveforms occurred over a time course that paralleled the time course of appearance of $I_{A}$ also support a role for $I_{A}$ in repolarization of the AP. Thus, it seems reasonable to conclude that $I_{A}$ is an important determinant of AP repolarization in rat SCG neurons and, in addition, that the appearance of $\mathrm{I}_{\mathrm{A}}$ during the embryonic development of these cells results in reshaping AP waveforms. An additional, presumably important, role for $\mathrm{I}_{\mathrm{A}}$ in some cells appears to be to regulate (or 'limit') excitability (Connor and Stevens, 1971b; Segal et al., 1984; Storm, 1986). Since $I_{A}$ activates on membrane depolarization at relatively hyperpolarized potentials and current activation is rapid, this conductance pathway will oppose increases in inward currents, thereby 'limiting' or slowing depolarization. In the presence of $I_{A}$, therefore, the time and/or the current required to reach the threshold to evoke an AP are expected to increase, and experimental observations support this suggestion (Connor and Stevens, 1971b). The observation here that smaller currents were required to evoke APs in E14.5-16.5 than in $\geq E 18.5$ cells ( $\leq 24 \mathrm{hr}$ after isolation) is consistent with there being a similar (important) role for $I_{A}$ in SCG neurons.

It would have been interesting to evaluate the electrophysiological properties of embryonic SCG ncurons at earlier times during development, particularly to evaluate the possibility that $\mathrm{Na}^{+}$current density and/or $\mathrm{Na}^{+}$current properties might vary during early development, as has been described in other systems (MacDermott and Westbrook, 1986; O'Dowd et al., 1988). Unfortunately, this was precluded by the difficulties associated with recognizing and isolating the SCG at earlier times (Rubin, 1985a). As noted previously, even in cultures prepared at E14.516.5 , morphologically distinct cell types were evident, suggesting contamination by cells not derived from the SCG. This hypothesis was supported by the observation that $\approx 30 \%$ of the neurons in E14.5-16.5 cultures did not bind 192-IgG, the monoclonal antibody directed against the NGF receptor (Chandler et al., 1984), indicating that these cells were most likely not sympathetic neurons (Richardson et al., 1986).

Previous studies in Xenopus spinal cord neurons also revealed changes in AP waveforms during development (Spitzer and Lamborghini, 1976; Baccaglini and Spitzer, 1977). Although the observed changes (in AP waveforms) in these cells were largely attributed to developmental variations in inward $\mathrm{Na}^{+}$and $\mathrm{Ca}^{2+}$ currents (Spitzer and Lamborghini, 1976; Baccaglini and Spitzer, 1977; Blair, 1983; Spitzer, 1983, 1984), more recent studies have revealed developmental changes in the amplitudes of voltage- and $\mathrm{Ca}^{21}$-dependent $\mathrm{K}^{+}$currents (O'Dowd et al., 1988), as well as in the $\mathrm{Ca}^{2+}$-sensitivity of $\mathrm{Ca}^{2+}$-dependent $\mathrm{K}^{+}$channels (Blair and Dionne, 1985). Most likely these changes are also important in reshaping AP waveforms in these cells (O'Dowd et al., 1988). In Ambystoma spinal neurons, developmental changes in outward $\mathrm{K}^{+}$currents also appear to be important in altering AP waveforms (Barish, 1986). Similarly, in Drosophila flight muscle, although $\mathrm{I}_{\mathrm{A}}$ appears early in development (Salkoff, 1981), a Ca ${ }^{2+}$-sensitive fast outward current, termed $I_{A C D}$, which is important in AP repolarization in the adult muscle, develops late (Salkoff, 1983). It seems certain that there is not a single pattern or sequence that is followed in all systems during the development of membrane excitability. Rather, it seems more reasonable to assume that the developmental changes that occur in neuronal membrane properties and the processes that regulate these changes are variable in different cells. It may also be that the detailed pattern followed during the development of excitable membrane properties is specific for a particular cell type and its physiological function. We anticipate that approaches similar to those employed here will help to clarify these points in a variety of neuronal cell types in the developing mammalian nervous system.

\section{References}

Adams, D. J., S. J. Smith, and S. H. Thompson (1980) Ionic currents in molluscan soma. Annu. Rev. Neurosci. 3: 141-167.

Baccaglini, P. I., and N. C. Spitzer (1977) Developmental changes in the inward current of the action potential of Rohon Beard neurones. J. Physiol. (Lond.) 271: 93-117.

Bader, C. R., D. Bertrand, and A. C. Kato (1983a) Membrane currents in a developing parasympathetic ganglion. Dev. Biol. 98: 515-519.

Bader, C. R., D. Bertrand, E. Dupin, and A. C. Kato (1983b) Development of electrical properties of cultured avian neural crest. Nature 305: 808-810.

Bader, C. R., L. Bernheim, and D. Bertrand (1985) Sodium-activated potassium current in cultured avian neurons. Nature $317: 540-542$.

Barish, M. E. (1986) Differentiation of voltage-gated potassium current and modulation of excitability in cultured amphibian spinal neurones. J. Physiol. (Lond.) 375: 229-250.

Belluzzi, O., O. Sacchi, and E. Wanke (1985a) A fast transient outward current in the rat sympathetic neurone studied under voltage clamp conditions. J. Physiol. (Lond.) 358: 91-108.

Belluzzi, O., O. Sacchi, and E. Wanke (1985b) Identification of delayed potassium and calcium currents in the rat sympathetic neurone under voltage clamp. J. Physiol. (Lond.) 358: 109-130.

Blair, L. A. C. (1983) The timing of protein synthesis required for the development of the sodium action potential in embryonic spinal neurons. J. Neurosci. 3: 1430-1436.

Blair, L. A. C., and V. E. Dionne (1985) Developmental acquisilion of $\mathrm{Ca}^{2+}$-sensitivity by $\mathrm{K}^{+}$channels in spinal neurones. Nature 315 . 329-331.

Carbone, E., and H. D. Lux (1984) A low voltage-activated calcium conductance in embryonic chick sensory neurons. Biophys. J. 46:413418.

Chandler, C. E., L. M. Parsons, M. Hosang, and E. M. Shooter (1984) A monoclonal antibody modulates the interaction of nerve growth factor with PC12 cells. J. Biol. Chem. 259: 6882-6889

Christie, G. A. (1964) Developmental stages in somite and post-somite rat embryos, based on external appearance, and including some features of the macroscopic development of the oral cavity. J. Morphol. I14: 263-286.

Connor, J. A., and C. F. Stevens (1971a) Voltage-clamp studies of a transient outward current in gastropod neural somata. J. Physiol. (Lond.) 213: 21-30.

Connor, J. A., and C. F. Stevens (1971b) Prediction of repetitive firing behaviour from voltage clamp data on an isolated neurone soma. J. Physiol. (Lond.) 213: 31-53.

Fox, A. P., M. C. Nowycky, and R. W. Tsien (1987a) Kinetic and pharmacological properties distinguishing three types of calcium currents in chick sensory neurones. J. Physiol. (Lond.) 394: 149-172.

Fox, A. P., M. C. Nowycky, and R. W. Tsien (1987h) Single-channel recordings of three types of calcium channels in chick sensory neurones. J. Physiol. (Lond.) 394: 173-200.

Freschi, J. (1983) Membrane currents of cultured rat sympathetic neurons under voltage clamp. J. Neurophysiol. 50: 1460-1476.

Galvan, M., and C. Sedlmeir (1984) Outward currents in voltageclamped rat sympathetic neurones. J. Physiol. (Lond.) 356: 115-133.

Gurney, A. M., R. Y. Tsien, and H. A. Lester (1987) Activation of a potassium current by rapid photochemically generated steps of intracellular calcium in rat sympathetic neurons. Proc. Natl. Acad. Sci. USA 84: $3496-3500$. 
Hagiwara, S., and L. Byerly (1981) Calcium channels. Annu. Rev. Neurosci. 4: 69-125.

Hagiwara, S., K. Kusano, and N. Saito (1961) Membrane changes of Onchidium nerve cell in potassium-rich medium. J. Physiol. (Lond.) 155: 470-489.

Hamill, O. P., A. Marty, E. Neher, B. Sakmann, and F. J. Sigworth (1981) Improved patch-clamp techniques for high resolution recording from cells and cell-free membrane patches. Pfluegers Arch. 391: 85-100.

Hawrot, E. (1980) Cultured sympathetic neurons: Effects of cell-derived and synthetic substrata and development. Dev. Biol. 74: 136151.

Higgins, D., and H. Burton (1982) Electrotonic synapses are formed by fetal rat sympathetic neurons maintained in a chemically defined culture medium. Neuroscience $7: 2241-2253$.

Hirning, L. D., A. P. Fox, E. W. McCleskey, B. M. Olivera, S. A. Thayer, R. J. Miller, and R. W. Tsien (1988) Dominant role of N-type $\mathrm{Ca}^{2+}$ channels in evoked release of norepinephrine from sympathetic neurons. Science 239: 57-60.

Johnson, M. I., and V. Argiro (1983) Techniques in the tissue culture of rat sympathetic neurons. Methods Enzymol. 103: 334-337.

Kawai, T., and M. Watanabe (1986) Blockade of Ca-activated K conductance by apamin in rat sympathetic neurones. Br. J. Pharmacol. 87: 225-232.

Kostyuk, P. G. (1981) Calcium channels in the neuronal membrane. Biochim. Biophys. Acta 650: 128-150.

Latorre, R., R. Coronado, and C. Vergara (1984) $\mathrm{K}^{+}$channels gated by voltage and ions. Annu. Rev. Physiol. 46: 485-495.

MacDermott, A. B., and G. L. Westbrook (1986) Early development of voltage-dependent sodium currents in cultured mouse spinal cord neurons. Dev. Biol. 113: 317-326.

Mains, R. E., and P. H. Patterson (1973) Primary cultures of dissociated sympathetic neurons. I. Establishment of long-term growth in culture and studies of differentiated properties. J. Cell Biol. 59: 329345.

Marrion, N. V., T. G. Smart, and D. A. Brown (1987) Membranc currents in adult rat superior cervical ganglia in dissociated tissue culture. Neurosci. Lett. 77: 55-60.

Marty, A., and E. Neher (1983) Tight-seal whole-cell recording. In Single Channel Recording, B. Sakmann and E. Neher, eds., pp. 107122, Plenum, New York.

McAfee, D. A., and P. J. Yarowsky (1979) Calcium-dependent potentials in the mammalian sympathetic neurone. J. Physiol. (Lond.) 290: 507-523.

McCleskey, E. W., A. P. Fox, D. Feldman, and R. W. Tsien (1986) Different types of calcium channels. J. Exp. Biol. 124: 177-190.

Nerbonne, J. M., A. M. Gurney, and H. R. Rayburn (1986) Development of the fast, transient outward $\mathrm{K}^{+}$current in embryonic sympathetic neurones. Brain Res. 378: 197-202.

Nowycky, M. C., A. P. Fox, and R. W. Tsien (1985) Three types of neuronal calcium channels with different calcium agonist sensitivity. Nature 316: 440-443.

O'Dowd, D. K. (1983) RNA synthesis dependence of action potential development in spinal cord neurones. Nature 303: 619-621.

O'Dowd, D. K., A. B. Ribera, and N. C. Spitzer (1988) Development of voltage-dependent calcium, sodium, and potassium currents in Xenopus spinal neurons. J. Neurosci. 8: 792-805.

O'Lague, P. H., D. D. Potter, and E. J. Furshpan (1978a) Studies on rat sympathetic neurons developing in cell culture. I. Growth characteristics and electrophysiological properties. Dev. Biol. 67: 384403.
O'Lague, P. H., E. J. Furshpan, and D. D. Potter (1978b) Studies on rat sympathetic neurons developing in cell culture. II. Synaptic mechanisms. Dev. Biol. 67: 404-423.

Pappone, P. A., and M. D. Cahalan (1987) Pandinus imperator scorpion venom blocks voltage-gated potassium channels in nerve fibers. J. Neurosci. 7: 3300-3305.

Raff, M. C., K. L. Fields, S.-I. Hakomori, R. Mirsky, R. M. Pruss, and J. Winter (1979) Cell type-specific markers for distinguishing and studying neurons and the major classes of glial cells in culture. Brain Res. 174: 283-308.

Richardson, P. M., V. M. K. Verge Issa, and R. J. Riopelle (1986) Distribution of neuronal receptors for nerve growth factor in the rat. J. Neurosci. 6: 2312-2321.

Rogawski, M. A. (1985) The A-current: How ubiquitous a feature of excitable cells is it? Trends Neurosci. 8: 214-219.

Rubin, E. (1985a) Development of the rat superior cervical ganglion: Cell maturation. J. Neurosci. 5: 673-684.

Rubin, E. (1985b) Development of the rat superior cervical ganglion: Ingrowth of preganglionic axons. J. Neurosci. 5:685-696.

Rubin, E. (1985c) Development of the rat superior cervical ganglion: Initial stages of synapse formation. J. Neurosci. 5: 697-704.

Sakmann, B., and E. Neher (1984) Patch clamp techniques for studying ionic channels in excitable membranes. Annu. Rev. Physiol. 46:455472 .

Salkoff, L. B. (1981) Outward currents in developing Drosophila flight muscle. Science 212: 461-463.

Salkoff, L. B. (1983) Drosophila mutants reveal two components of fast outward current. Nature 302: 249-251.

Salkoff, L. B., and R. J. Wyman (1983) Ion currents in Drosophila flight muscles. J. Physiol. (Lond.) 337: 687-709.

Segal, M., M. A. Rogawski, and J. L. Barker (1984) A transient potassium conductance regulates the excitability of cultured hippocampal and spinal neurons. J. Neurosci. 4: 604-609.

Smith, P. G., T. A. Slotkin, and E. Mills (1982) Development of sympathetic ganglionic neurotransmission in the neonatal rat. Preand postganglionic nerve response to asphyxia and 2-dcoxyglucosc. Neuroscience 7: 501-507.

Spitzer, N. C. (1983) The development of neuronal membrane properties in vivo and in culture. In Developing and Regenerating Vertebrate Nervous Systems, P. Coates, ed., pp. 41-59, Liss, New York.

Spitzer, N. C. (1984) The differentiation of membrane properties of spinal neurons. In The Cellular and Molecular Biology of Development, I. B. Black, ed., pp. 95-106, Plenum, New York.

Spitzer, N. C., and J. E. Lamborghini (1976) The development of the action potential mechanism of amphibian neurons isolated in culture. Proc. Natl. Acad. Sci. USA 73: 1641-1645.

Storm, J. (1986) A-current and Ca-dependent transient outward current control the initial repetitive firing in hippocampal neurons. Biophys. J. 49: 369a.

Taniuchi, M., H. B. Clark, and E. M. Johnson, Jr. (1986) Induction of nerve growth factor receptor in Schwann cells after axotomy. Proc. Natl. Acad. Sci. USA 83: 4094-4098.

Thompson, S. H. (1977) Three pharmacologically distinct potassium channels in molluscan neurones. J. Physiol. (Lond.) 265: 465-488.

Wakshull, E., M. I. Johnson, and H. Burton (1979) Postnatal rat sympathetic neurons in culture. I. A comparison with embryonic neurons. J. Neurophysiol. 42: 1410-1425.

Wanke, E., A. Ferroni, A. Malgaroli, A. Ambrosini, T. Pozzan, and J. Meldolesi (1987) Activation of a muscarinic receptor selectively inhibits a rapidly inactivated $\mathrm{Ca}^{2+}$ current in rat sympathetic neurons. Proc. Natl. Acad. Sci. USA 84: 4313-4317. 